Illinois State University

ISU ReD: Research and eData

Theses and Dissertations

5-25-2019

\title{
Yerba Mate: National Project to Emerging Superfood
}

Ana Fochesatto

Illinois State University, anacf7@gmail.com

Follow this and additional works at: https://ir.library.illinoisstate.edu/etd

Part of the Social and Cultural Anthropology Commons

\section{Recommended Citation}

Fochesatto, Ana, "Yerba Mate: National Project to Emerging Superfood" (2019). Theses and Dissertations. 1136.

https://ir.library.illinoisstate.edu/etd/1136

This Thesis is brought to you for free and open access by ISU ReD: Research and eData. It has been accepted for inclusion in Theses and Dissertations by an authorized administrator of ISU ReD: Research and eData. For more information, please contact ISUReD@ilstu.edu. 


\section{YERBA MATE: NATIONAL PROJECT TO EMERGING SUPERFOOD}

\section{ANA FOCHESATTO}

\section{Pages}

Yerba mate, Ilex paranguariensis, is a shrub commonly found in the Atlantic Forest of South America which covers part of northeast Argentina, eastern Paraguay, and southern Brazil. The dried leaves and stem of the tree are used to make an infusion, called mate, used first by indigenous Guaraní people. Today, yerba mate is widely consumed in the Southern Cone region and is regarded as the national drink of Argentina, Paraguay, and Uruguay. I argue that yerba mate has entered the U.S. as a "superfood," marketed as a product with nutritional and symbolic medicinal values.

In this thesis, I trace yerba mate's construction as a symbol of Argentine national identity which entailed both the exploitation of indigenous labor and erasure of the mate's indigenous roots. I show that this history continues to be relevant for understanding the meaning of yerba mate today in Argentina. I focus specifically on two successful yerba mate brands, Taragüi and Titrayju. Drawing on a semiotic analysis of product packaging and a discourse analysis of contemporary media narratives on yerba mate, I situate these brands within a larger historical context. I then follow yerba mate transnationally with an analysis of its more recent marketing to U.S. consumers.

I focus on the most popular yerba mate brand, Guayakí, that markets yerba mate as a superfood and as a socially and environmentally sustainable product to young consumers. 
Despite different yerba mate narratives across the Americas, as a national symbol and as a transnational superfood, very similar historical processes continue to undermine indigenous rights and identity in both its place of origin and in its new U.S. market.

KEYWORDS: Yerba Mate; Nationalism; Superfood; Indigeneity; Health; Nutrition; South America; Argentina; United States 
YERBA MATE: NATIONAL PROJECT TO EMERGING SUPERFOOD

ANA FOCHESATTO

A Thesis Submitted in Partial

Fulfillment of the Requirements

for the Degree of

MASTER OF ARTS

Department of Sociology and Anthropology

ILLINOIS STATE UNIVERSITY 
(C) 2019 Ana Fochesatto 
YERBA MATE: NATIONAL PROJECT TO EMERGING SUPERFOOD

ANA FOCHESATTO

COMMITTEE MEMBERS:

Gina Hunter, Chair

Nobuko Adachi 


\section{ACKNOWLEDGMENTS}

I would like to express my gratitude to my committee, Gina Hunter and Nobuko Adachi, for guiding and supporting my work. Gina provided me with many valuable conversations, feedback, and encouragement. I also wish to acknowledge the entire ISU Department of Sociology and Anthropology, faculty and staff, for nurturing a positive and productive learning environment that helped me discuss and develop the ideas in this thesis. I would not have been able to complete this work without the opportunity of this master's program presented by the Stevenson Center for Applied Community and Economic Development. As in all endeavors, this work was possible only with the love, patience, and support of my family and friends.

A.F. 


\section{CONTENTS}

Page

ACKNOWLEDGMENTS

FIGURES

INTRODUCTION AND METHODS

LITERATURE REVIEW 11

National Cuisines and Modernity: Rise of Print Media and Technological Advances 12

$\begin{array}{ll}\text { Food as Ethnic Identity } & 17\end{array}$

$\begin{array}{ll}\text { The Food Movement } & 21\end{array}$

CHAPTER I: THE WHITE YERBA MATE NATION 26

Argentine Yerba Mate Territory $\quad 31$

Las Marias Company Profile $\quad 34$

Taragüi: La preferida por los Argentinos 36

$\begin{array}{ll}\text { Yerba Mate Argentina } & 41\end{array}$

CHAPTER II: YERBA MATE OF THE RESISTANCE 46

Cooperativa Agrícola Río Paraná Profile 46

Los Colonos y La Resistencia

From the Hands of the White Misionero $\quad 52$

Visibility for the Mbya Guaraní 56

CHAPTER III: SUPER YERBA AND AMERICAN SAVIORS 59

Guayakí Company Profile $\quad 60$

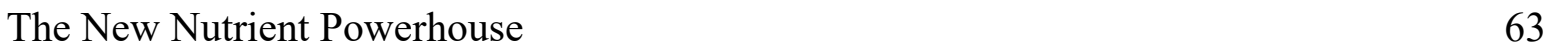

Your Morning Fix: Empire and Capital Extraction 67

$\begin{array}{ll}\text { The Yerba Mate Drinker and Activist } & 70\end{array}$ 
$\begin{array}{ll}\text { DISCUSSION } & 84\end{array}$

$\begin{array}{lr}\text { CONCLUSION } & 88\end{array}$

$\begin{array}{lr}\text { REFERENCES } & 90\end{array}$ 


\section{FIGURES}

Figure $\quad$ Page

1. "To share a mate" 4

2. "Foreign exchange students are integrated through mate" 29

3. Analysis of Taragüí Product Label by Author 37

4. Taragüi on INYM Website $\quad 40$

5. Geographical Indication Obtained by INYM 42

6. Twitter Post Made by Taragüi on Nordelta Incident 45

7. Analysis of Titrayju Product Label by Author 53

8. Titrayju Benefits $\quad 54$

9. Titrayju Statement on Production $\quad 55$

10. Guayakí Product Label Front and Side 65

11. Google Search for Yerba Mate 65

12. Guayakí Product Label Back 76

13. Yerba Mate Blog Description $\quad 79$

14. Guayakí: Everything You Ever Wanted to Know 80

15. Guayakí New Label $\quad 83$ 


\section{INTRODUCTION AND METHODS}

Yerba mate, Ilex paranguariensis, is a shrub native to the Atlantic Forest of South America which covers part of northeast Argentina, eastern Paraguay, and southern Brazil. The Atlantic Forest, like the Amazon, is known for its incredible biodiversity but monoculture plantations of soy and other crops including yerba mate have contributed to vast deforestation (Ribeiro et al. 2011). In its early stages of growth, the yerba mate plant resembles tea, (Camellia sinensis sp.), yet with rounder and brighter, green-colored leaves. Like Camellia sinensis, people in the region have harvested and consumed yerba mate for centuries in an infusion that has had important social and economic effects. Yerba mate is mostly grown in monoculture plantations with some farms utilizing a shade-growing technique. Aside from issues of deforestation, the yerba mate region of Argentina has some of the highest rates of poverty and extreme poverty in the country (Manzano and Duciós 2019). Tareferos, the laborers who harvest yerba mate annually, are heavily exploited and yerba mate fields are known for having child labor as well as forced labor of the indigenous Guaraní people of the region. ${ }^{1}$ Furthermore, land consolidation and unequal access to farming technologies have increasingly monopolized the market with four companies controlling 80 percent of the Argentine market (Ballvé 2007).

Yerba mate was first used by indigenous Guaraní people and was popularized during the colonial era. The dried leaves and stem of the tree are used to make an infusion, called mate. Today, Argentina, Paraguay, and Uruguay all claim it as their national drink or infusion. Although the drink is consumed throughout Brazil, it is most popular in the southern region of the country. Yerba mate is most popularly consumed in an infusion prepared with water in a hollow gourd and

\footnotetext{
${ }^{1}$ Local newspaper article on forced labor: https://www.infobaires24.com.ar/misiones-guaraniesobligados-trabajar-tareferos-12-horas-cien-pesos/
} 
sipped through a straw made of metal or sugar cane known as bombilla. Its widespread consumption has made it a staple of most households of the Southern Cone. Sipping yerba mate is an everyday social occurrence that promotes a sense of solidarity between participants (Lawson $2009,5)$. One person, the cebador, is in charge of pouring hot water from a thermos into the yerba mate gourd and passing it to other participants in corresponding turns. Each person gets a turn sipping all the liquid from the gourd before passing it back to the cebador who pours water for the next person. This practice can vary slightly depending on the region and on personal preferences. For example, in Paraguay and northeastern Argentina the infusion is sometimes consumed cold or with juice and called tereré. I have also seen people add different fruits or herbs to the yerba mate gourd to sweeten or change the taste. Others insist that yerba mate should only be consumed bitter with no flavor additives and with hot water only.

I learned the traditional way of drinking yerba mate out of a gourd from my family in Argentina and continue to consume it when I visit friends and family in Argentina or whenever I spend time with my parents both of which are loyal to their yerba mate drinking ritual no matter how much coffee advertising they see in the United States. Growing up in the United States, I never developed the habit of drinking yerba mate, opting instead for coffee or tea. My family is originally from Entre Rios in the northeastern region of Argentina, close to Misiones and Corrientes where all yerba mate in Argentina is produced. Although mate drinking is popular throughout Argentina and has become a symbol of national identity, consumption in the northeastern region is especially high. Traveling back and forth between the United States and Argentina often made me ponder the cultural, social, and economic similarities and differences of these two places. My upbringing in this liminal cultural space has informed my anthropological questions about yerba mate. As an undergraduate student in anthropology, I 
became increasingly interested in understanding the social mechanics of yerba mate drinking because I felt that it was one of the stark differences between my everyday life in the United States and my visits to Argentina.

I interviewed my friends and family to understand the reasons why they consumed yerba mate so routinely. I conducted fieldwork in a large yerba mate plantation, Las Marias, in the northeast province of Corrientes. My undergraduate thesis, "Mate Drinking in the Semiotic Construction of Sociality and Imagined Community in Latin America" analyzed the social infrastructures and bonds created by yerba mate in Argentina and compared it to other drinks in the United States.

Yerba mate production is limited to the Atlantic Forest region, but yerba mate consumption has recently started to grow worldwide after many failed attempts since the nineteenth century to bring the drink outside of the Southern Cone (Folch 2010, 19). While writing my undergraduate thesis, I was surprised by the curious appearance of yerba mate in the organic aisles of my local grocery store in the U.S. This new import to the United States came with marketing and consumption practices that were very different than what I practiced growing up and what I saw in my research in Argentina.

My continued interest in yerba mate has led me to ask many more questions about the role it plays in Argentine society and its new, emerging role in the United States. In both places, I have confronted tidy, often unreflexive, origin stories about yerba mate. In Argentina, my informants often described it as something quintessentially Argentine. In the United States, I have often encountered yerba mate as tea or energy drink in organic aisles, advertised as a health food. Because there has been little anthropological research done on yerba mate previously, there are many questions to ask about this unassuming drink. However, I am particularly fascinated by 
the emergence of yerba mate in the United States and specifically by the different marketing messages, prescribed consumption patterns, and advertised health claims. In this thesis, I researched the marketing and media narratives of yerba mate to provide a better understanding of its symbolic representations in Argentina and the United States. The everyday and ritualistic consumption of yerba mate in Argentina makes this food item especially important for the study of larger cultural processes and identity.

Figure 1 shows an image that I have encountered on social media several times. The image depicts one person passing the yerba mate gourd to another in what looks like a mateada or a gathering where people sit in a round and drink yerba mate while having casual conversation. The text in the image reads, "To share a mate is to share, stories, joys and cries, it is finding oneself"2 (Figure 1).

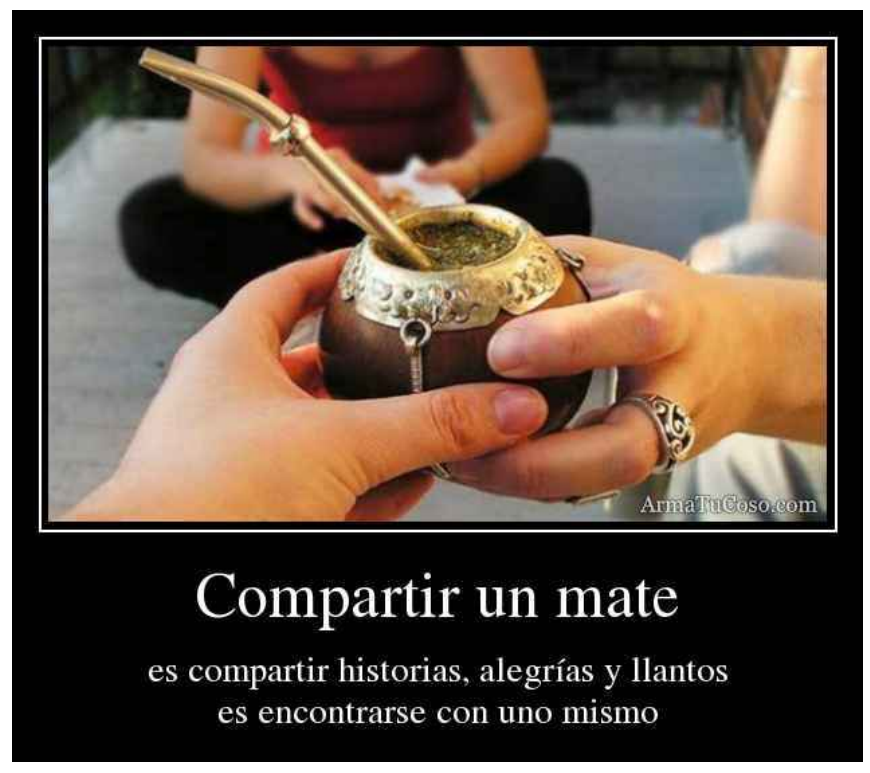

Figure 1. "To share a mate." Retrieved May 20, 2019 from http://offtopic.dailypostoffice.com/post/143550/C\%C3\%B3mo-Se-Prepara-Un-Buen-Mate-Info

\footnotetext{
${ }^{2}$ All translations are my own.
} 
As a social practice, yerba mate drinking is conceived as a medium for sociality that promotes social cohesion and horizontalizes power relations. Further, yerba mate's status as a national infusion in Argentina makes it central to questions of citizenship and political identity. Although many studies have focused on understanding the production of yerba mate, its economic impacts in South America, its implications for labor and deforestation, there has been little research that delves into the social and political implications of its consumption. Some studies have traced the significance of yerba mate production in the colonization of the region as a powerful economic and cultural tool for the emerging Argentine nation-state (Rau 2008).

While mate may be valued for its important social function and its place as a national symbol, it also holds a sordid history of colonization that persists today with issues related to indigenous land claims, conservation, and extreme poverty. In 2018, María Josefa Ramirez, the National Coordinator of El Equipo Nacional de Pastoral Aborigen (ENDEPA) reported that of the 120 Mbya Guaraní communities in Misiones, only 27 have legal titles to land. ${ }^{3}$ As a result, the way that the history of yerba mate is presented is an important insight into how Argentina deals with its history of colonization and subjugation of indigenous people. It is important to connect how these cultural and political processes continue to be reconstructed and reaffirmed in contemporary, quotidian consumption. Furthermore, the introduction of yerba mate to a new group of consumers in the Global North provides a unique opportunity to study the cultural narratives and power structures embedded in its new, emerging representation which I argue is in line with the recent rise of the "superfood" concept. While the food movement and the recent calls for re-conceptualizations of food and eating in the United States have sought to connect

\footnotetext{
${ }^{3}$ Guaraníes pidieron al Gobernador que convoque a un referendum. 2018. Retrieved on May 20, 2019 from http://www.primeraedicion.com.ar/nota/100054136/guaranies-pidieron-algobernador-que-convoque-a-un-referendum/
} 
consumers to the realities of agricultural production sites, these efforts still exist within a framework of settler colonialism that affects marketing narratives and perceptions of both production sites and their laborers, often indigenous or peasant communities.

This research focuses on yerba mate narratives and the communities of the Atlantic Forest region, but the yerba mate narratives I found in the United States are shaped by American notions of indigeneity, food, and imperialism. As of 2013, poverty rates among indigenous communities in the Unites States were over 60 percent in some reservations with an overall national average of 28.4 percent, well above the 15.3 percent national poverty rate (Bennet et al. 2014). Likewise, in Argentina, the invisibility and marginalization of indigenous groups is wellknown by researchers and human rights activists. Mutuma Ruteere, U.N. Special Rapporteur on Racism and Related Intolerance, stated in 2016 that "the situation of indigenous people in certain areas of the country is appalling as they live in extreme poverty, isolation from others and without access to basic services" (Moloney, 2016). Focusing on narratives of nationalism in the context of indigenous rights is crucial amidst a growing crisis of climate change where nationstates and corporations continue to advance on indigenous lands for the extraction of key natural resources. If political and social discourse and action on the issue does not change, the climate crisis will exacerbate the already unequal access to land and rights to food.

Focusing on yerba mate is one way to begin to diagram the political and cultural frameworks that uphold a system of dispossession. The study of food has great anthropological value because it is essential for human existence and of great symbolic and social significance. The need to follow specific food items across space and time has become increasingly important in a globalized food system. As food mediates political power, its study is critical for our understanding of market forces, capital flows, political representation and more largely, political 
structures like the nation-state. Previous scholars have shown that the study of single commodities can unveil many realities about class struggles, ethnic identities, gender, and other issues (Mintz 1986, Ohnuki-Tierney 1994). In understanding them as commodities, these studies have shed light especially on capital flows and empire building with a particular emphasis on historical contexts that unveil their material and symbolic transformations throughout time and space.

Similarly, the biography of things approach introduced by Kopytoff (1986) posits that material objects have, as human subjects, social lives to be investigated. The materiality, function, symbolism, and importance of an item by certain actors and in different contexts construct people's understandings of value and power. An object that may be commodified in one place may be devoid of any monetary value in another time and place. In this thesis, I am interested in following yerba mate through some of these transformations. I am particularly interested in asking about its current forms as a national symbol in Argentina and as an exotic health food in the United States. Thus, the biography of things methodology takes me to conduct a multi-sited study that creates "...the form of juxtapositions of phenomena that conventionally have appeared to be (or conceptually have been kept) 'worlds apart."” (Marcus 1995, 102). As also theorized by Hooker (2017), I focus on juxtaposing my findings of yerba mate across the Americas to lend a hemispheric lens to the conceptions of nation, race, and class. Food items like yerba mate which are portrayed plainly as national symbols through popular discourse, legislation, and government funding are important mediums through which to better understand nationalism and its implications for political representation and land claims.

In the field of linguistic anthropology, semiotic analysis has become an important method in studies pertaining to the consumption of food and it is especially appropriate for this study's 
focus on nationalism. Since semiotics deals with the meaning making of signs, food is an interesting area of research because of its rich material and symbolic importance in mediating values and social relations. The study of food "frequently starts with language: what people say about food, how they speak about it, what they do not say about it, and what they say that hides or stands for something else" (Cavanaugh et al. 2014, 85). Further, as Stano (2016) summarizes, the recent "gastromaniac" era has increased the symbolic and communicative aura surrounding food $(2016,20)$. With increasing globalization, Ichijo and Ranta (2016) explain that food labeling and marketing by companies and governments is exhibiting more, not less banal nationalism. Identifying and analyzing these discourses and their implications is part of teasing out the world that is present and signified in food. As Barthes ([1961] 2012) states, "today we have a tool with which to isolate these themes and situations, namely, advertising" ([1961] 2012, 32). Advertisements assign meanings and functions to food by engaging with societal myths and recreating them. For example, Barthes analyzes how advertising of French food allows the consumer to:

...partake each day of the national past. In this case, this historical quality is obviously linked to food techniques (preparation and cooking). These have long roots, reaching back to the depth of the French past. They are, we are told, the repository of a whole experience, of the accumulated wisdom of our ancestors. ([1961] 2012, 34)

The usefulness of studying discourse about food in the context of political representation and the nation-state took me to conduct a semiotic analysis of yerba mate product labeling, media, and government discourse pertaining to three different products where yerba mate has been commodified around vastly different myths for different purposes and audiences. I used secondary sources and archival evidence to inform this analysis and to trace the particular historical context of yerba mate that has caused it to be commodified in those specific ways. The historical literature situates the marketing strategies and discourse within larger empire building 
practices. Further, I summarized production, consumption, import and export data on yerba mate in the Argentine and American markets.

I collected company information, product labels, and marketing materials from the websites of each company and from third-party online vendors such as Amazon and Mercado Libre. Aside from mission statements, production details, and company histories, I analyzed content marketing and reports publicly available on their websites. To delve deeper into the cultural understandings informing these marketing strategies, I analyzed three Argentine government documents and five reports by regulatory agencies like the INYM and CRYM (as explained in Chapter I). For Guayakí, I investigated a B Corp report also publicly online. I conducted Google searches for "yerba mate" where I found top hits that included newspaper articles, blogs, and health and wellness articles. I analyzed three webpages from the "Yerba Mate Blog" and "Circle of Drink," as well as four different American online health articles on yerba mate from webpages including Mayo Clinic and Healthline. Further, I analyzed fourteen newspaper articles from prominent news outlets in Argentina and the U.S., such as Clarín and the New York Times respectively. I also analyzed social media posts that I found were in conversation with the discourse in these newspaper articles.

With the semiotic analysis of product labeling and media discourse, a historical contextualization, and market data, I shed light on yerba mate's role in the everyday reproduction of the nation-state and its implications on conceptions of race and class with particular attention to the political representation of indigenous peoples. I chose to analyze the cases of Taragüi, Tritrayju, and Guayakí because their popularity suggests that their marketing is or was at one point widely approved and authenticated by consumers and because juxtaposing marketing narratives hemispherically (by examining brands both in North and South America) can shed 
light on the power structures behind the material and symbolic transformation of yerba mate domestically and across the American continent. Through these cases, I follow what has become a transnational commodity and is embedded in complex processes of nation-building and empire. In particular, the analysis takes me to analyze the rising popularity of health foods often referred to as "superfoods" and their entanglement with claims and desires for sustainability, critical consumption, and connection to indigenous communities.

In the following section, I review the literature on studies of food like yerba mate that have strong nationalistic implications. In Chapter I, I delve deeper into the background of yerba mate including its production, consumption, and cultural understandings as studied by previous scholars. I review the historical understandings linked to the business of yerba mate production and consumption in the Southern Cone, and I use these to inform the semiotic analysis of the bestselling yerba mate in Argentina, Taragüi. In Chapter II, I continue to analyze yerba mate narratives in Argentina by presenting an analysis of the yerba mate brand, Titrayju, a small cooperative in Misiones. In Chapter III, I trace yerba mate's emergence into the United States to analyze how it is marketed to consumers through the Guayakí yerba mate brand. In the United States, yerba mate can be found in health food stores and in organic sections of many supermarkets as a tea, juice, supplement and in many other forms that promise a myriad of health benefits. Despite different yerba mate narratives across the Americas, as a national symbol and as a transnational superfood, very similar historical processes continue to undermine indigenous rights and identity in both its place of origin and in its new U.S. market. 


\section{LITERATURE REVIEW}

Over the last two decades, scholars have increasingly begun to center food items like yerba mate in their research. Counihan and Esterik (2012) account the rise of food literature to how feminism and women's studies have legitimized it as a domain of human study which has long been associated with women in many cultures. Another reason has been the rise of food movements that have politicized food and eating, questioning food production, distribution, quality and healthfulness. It is within the context of these recent food movements that yerba mate and other foods have been transformed into new products where marketing addresses some of these questions and concerns through stories about production sites and organic certifications. As a scholarly pursuit, food has become an incredibly rich, interdisciplinary topic that encompasses a large scope of issues pertaining to "how food links body and soul, self and other, the personal and the political, the material and the symbolic" (Counihan and Esterik 2012, 2).

Food is a powerful vehicle for the construction of personal and community identity. Food as a symbol of group identity can include, exclude and define individuals within a group. This is done both through its consumption in social rituals that serve to bring people together and through popular discourse that imagines and re-imagines historical narratives, ideas of authenticity, and definitions of boundaries and belonging. In this way, many scholars have begun to see how the creation and contestation over national cuisines and national food symbols has contributed to national imaginaries. Considering that yerba mate has been declared a national infusion/drink by law in Argentina, Paraguay, and Uruguay, it is an important food item to focus on for the study of national imaginaries in these countries.

The topic of food is of special interest to historians and anthropologists who hope to understand how globalization and increasing interconnectedness continues to affect the politics 
of the nation-state. Thus, this study's focus on yerba mate as a new health superfood in the United States also speaks to some of the complicated issues surrounding the global food system. In the following section, I review some of the literature on how scholars have understood foods as symbols of national identity and as means of communication that index power relations and identity in Argentina, the United States, and throughout the world. Overall, the literature points out that national cuisines and national imaginaries have developed through the rise of print media and technological advances as well as through top-down government policies, appropriation by the elite, and negotiations and contestations over food symbols along lines of class and ethnicity.

The national cuisines of Argentina and the United States are considered to be a mix of immigrant foods and regional specialties rather than their own unique cuisine (Pite 2013, 88). Even in a melting pot of flavors, lines are drawn as to what is truly included in the national diet and what is not. Further, indigeneity holds a problematic place in the idea of the immigrant nation as is reflected in American cuisine by Siskind's study of the Thanksgiving turkey and in Pite's analysis of Argentina's Doña Petrona where Argentine cuisine clearly sets European style of cuisine at the center of the table. Rising food movements seem to be questioning some of the injustices of the food system, often centering indigenous and peasant communities who are most exploited but there is debate as to the effectiveness of some of the strategies employed.

\section{National Cuisines and Modernity: Rise of Print Media and Technological Advances}

Scholars have connected food and the creation of the nation with the invention of print media and mass dissemination of cookbooks and recipes. Appadurai's (1988) study of cookbooks in India shows how the rise of print media, as well as the cultural rise of a new middle class aided the creation of a national Indian cuisine in the 1960s-80s. This national Indian cuisine 
incorporated regional flavors, which, although contrasted with one another, created an imagined and united nation out of distinct regional traditions. The Indian case was presented as an early model of how societies with recently acquired nationhood and a postindustrial, postcolonial middle class could construct a "particular sort of polyglot culture" (Appadurai 1988, 5).

The rise in print media and a growing middle class were important factors for the creation of these cookbooks and the rise of a national cuisine because they created the possibility of social interaction between middle class women where they could exchange recipes with each other across regional lines (Appadurai 1988,7). The consumption of these print materials outlining a national cuisine, created a national Indian imagined community. Anderson (1991) describes that all communities that are larger than self-contained villages affording regular face-to-face contact with all inhabitants are imagined communities. He defines these imagined communities as imagined because "the members of even the smallest nation will never know most of their fellow-members, meet them, or even hear of them, yet in the minds of each lives the image of their communion" (Anderson 1991, 7). Anderson analyzes national identity and nationalism by arguing that through the invention of the print press and the growth of industrial capitalism in Europe, people were able to create a national consciousness.

Cookbooks, as print media, served to articulate an imagined community and national consciousness in India through the creation of a national cuisine with distinct regional flavors that incorporate people from throughout the country. Although this incorporation of regional flavors does not aim to deny regional or ethnic roots, Appadurai does explain that there is a process of standardization that happens through the rise of the urban middle class. These middleclass families, specifically urban middle-class women, who choose certain flavors or dishes over others in commensality or in recipe exchanges make up the basis for the cookbooks that are 
printed and mass distributed (Appadurai 1988, 7). Although commensality marked ethnic and caste boundaries, Appadurai states that "the homogenization of a certain middle-class lifestyle calls for the diversification of consumption pattern" $(1988,7)$. In other words, the formation of Indian national cuisine happens through the rise of a cosmopolitan middle class that loosens the boundaries between regions and castes and unites foods and peoples through a homogenized, standardized national cuisine. The result is an elimination of the most peculiar or distinctive food practices, a reduction of nuances in regional differences, and process in which regional traditions that have "greater access to urban resources, institutions and media are pushing humbler neighbors out of the cosmopolitan view" $(1988,18)$. Appadurai concludes that although the structure of the Indian meal created by these authors "creates strange regional and ethnic bedfellows... it facilitates the collection and dissemination of regionally and ethnically variable recipes" (Appadurai 1988, 20). Appadurai presents a processual model to the creation of national cuisines in post-colonial nation-states that underscores the rise of an urban middle-class, the role of women and the global exchanges that contribute to recipe exchanges making up the standardization of a national cuisine.

In the case of Argentina, Pite (2013) follows the life and work of Doña Petrona C. de Gadulfo to examine Argentine cuisine in the twentieth century. Doña Petrona's cookbook first published in 1934 was not only the most popular cookbook in Argentine history but also the best-selling book of all time on par with the Bible and Martín Fierro $(2013,20)$. Pite states that although Doña Petrona's cookbook did contribute to an imagined Argentine community, "in contrast to Anderson's vision, this sense of community did not emerge in the period leading up to independence, but rather during the course of the twentieth century" $(2013,21)$. Similar to Appadurai, Pite's analysis unveils the ways in which middle class women were key to shaping 
this imagined community. Doña Petrona migrated to Buenos Aires from the Argentine interior in the 1920s. She began her career as a home economist for a British gas company where she demonstrated new appliances and wrote her famous cookbook, El libro de Doña Petrona. Her cookbook, magazine columns, and later radio and TV shows provided intricate recipes that instructed women who aspired to be respectable or middle class with advice on how to properly set a table or serve a meal (Pite 2013,25). As Pite (2013) explains, although the cookbook was not overtly nationalistic,

She codified a version of Argentine cuisine that combined sensibilities of provincial home cooks with indigenous and Spanish culinary roots, the influence of the cuisine brought by immigrants (most from Italy and Spain), and the self-conscious internationalism of elites in Buenos Aires, who celebrated French cuisine. $(2013,25)$

Pite also goes on to note that the cookbook's popularity and success led to a notion that the book had made its way into "every Argentine home" $(2013,37)$. With this logic, those who did not have access to Doña Petrona were excluded from this imagined community. As Pite explains, "rural indigenous and mestizo poor and those who worked as domestic servants were frequently not able, invited, or imagined to take a seat at Argentina's metaphorical common table" (2013, 37). In this way, the dissemination of Doña Petrona's cookbook among the urban, middle class who could afford the book became to represent the nation. Pite also interviews working class and provincial women who mention that they did not have access to the book or to the means to cook such expensive recipes. The frills of Doña Petrona's cooking were not compatible with the subsistence diet of poor Argentines who mostly depended on mate and crackers (Pite 2013, 212). Although yerba mate has been a staple of the poor and working class, it is particularly interesting to me to trace some of the processes and cultural notions through which mate has become a national symbol and permeated so many more sectors of society. The Martín Fierro, an epic poem by José Hernandez published in 1872, is another best-selling book of all time in Argentina. 
The poem recounts the life and adventures of the gaucho in the Argentine pampa, as well as the gaucho's role in the development of Argentina and independence from Spain. The archetype of the guacho became significant in Argentine mythology and popularized yerba mate drinking. Yet, while the literature and discourse of popular media has great impact on the national mythology another important factor to consider in these processes is the role of institutions in endorsing certain products or consumption patterns over others.

Bruegel (2002) explains how the French learned to eat canned food in the late nineteenth century. French confectioner Nicolas Appert, inventor of airtight food preservation, was appalled by the French population's resistance to the consumption of sterile foods. Food preservation techniques, he argued, could eliminate seasonal starvation and provide healthier and safer food supply for the French peasants and the middle class. However, these solutions were resisted by "lower-class people who appeared to insist on direct and timely provenance of foodstuffs on their tables" with a "predilection for fresh foodstuffs" $(2002,117)$. Bruegel shows that print media and medical journals at the time reinforced fears that canned food could cause lead poisoning and botulism $(2002,118)$. Governmental institutions, on the other hand, insisted that canned food could be advantageous and systematically imposed them on the population through the publicschool system and the military. In Argentina, Pite analyzes how the economic changes and political turmoil throughout the twentieth century affect access to Doña Petrona. For example, Pite shows that when Juan and Eva Perón took office in 1946, they distributed millions of loaves of pan dulce and bottles of cider for the Christmas holiday, enabling working class families who did not have the time to bake Doña Petrona's pan dulce or the money to buy it at a bakery (2013, 109). Yerba mate has also been subject to many government subsidies, especially more recently 
as prices have gone up and the regulatory agency, the National Institute of Yerba Mate (INYM), has been tasked with keeping prices fair for producers and low for consumers.

Other struggles in the creation of a French national cuisine also involve a tension between scientific discoveries and technological advances with urban versus rural patterns of consumption. Boisard's (2003) study of camembert cheese points out that the origin of this cheese coincides with the birth of the French republic and how its history is interwoven with the struggles of French national identity. Consequently, camembert's white aesthetic became a symbol of the sanitation of the countryside, and discussions over pasteurized vs. unpasteurized Camembert became struggles over tradition versus modernity. The technology of pasteurization and the commercialization of camembert led to a transformation of the nineteenth century cheese that through its standardization, marketing and national distribution networks became a national symbol of French identity for domestic and foreign consumption. Similarly, my analysis will also show some of the tension between the urban-rural divide in the consumption of yerba mate, where despite its national relevance yerba mate continues to be connected to the provincial poor.

\section{Food as Ethnic Identity}

As national symbols, foods are at the center of popular discourse and social struggles related to the rise of the middle class, the rise of cosmopolitanism, modernity and its implications on personal health. Because of the historicity of food and its connections with national histories, the perception of food and nation can change power dynamics of certain groups of people within the nation-state. An important example of this is Munasinghe (2001)'s study on cultural politics of identity in Trinidad in the 1980s and 1990s. In this historical and ethnographic work, Munasinghe explores the significance of "race" and "ethnicity" as cultural and political 
constructs. Through a case study of Trinidad, Munasinghe shows how these struggles create nationalisms that are different than the white European models of nationalism. Within Trinidad, Munasinghe sees a nationalist project that rests on ancestral diversity and multiculturalism. East Indians in Trinidad are excluded from the national identity as Indian cultural identity is set in opposition to Afro-Caribbean culture. Their strategy is to redefine what it means to be

Trinidadian. Indo-Trinidadian leaders do this in popular discourse by:

Counterimposing the image of a tossed salad to that of a callaloo, a popular dish in the Caribbean in which a number of distinct ingredients are boiled down to a homogenous mush. The callaloo is a clear analogy to the melting-pot model of assimilation; the imagery of a tossed salad, in which each piece of lettuce and cucumber retains its 'true' identity despite being mixed with 'other' ingredients, draws on the plural society model of the coexistence of different (and sometimes incompatible) cultural institutions.... Indo-Trinidadians are quick to opt for a tossed salad analogy. $(2001,22)$

Through the tossed salad, Indo-Trinidadians attempt to change what it means to be Trinidadian so that this national image can recognize Indian identity as Trinidadian identity.

The question of multiculturalism and the incorporation of certain ethnic identities into the national identity is an important issue. As I have noted, Argentine cuisine is made of immigrant foods and regional specialties and what gets highlighted and who has access to it defines the borders of the imagined community. Also, as a nation of immigrants in the New World, the United States has a mixture of many different food traditions and shares a common history of oppression and marginalization of indigenous people. The U.S. is often described in popular and scholarly discourse as an ethnic melting pot which extends to discussions about food. Gabaccia (1998) argues that "what unites American eaters culturally is how we eat, not what we eat. As eaters, all Americans mingle the culinary traditions of many regions and cultures within ourselves" (Gabaccia 1998, 226). Gabaccia (1998) states that America is a place of multi-ethnics choosing among an array of different foods and coming together in a great melting pot. As such, 
Gabaccia presents the culinary history of the United States as a tradition of multicultural foods and actors negotiating, borrowing, and adapting American eating through entrepreneurship and connoisseurship. Further, through corporate mass production and advertising certain foods like bagels and pizza become so "Americanized" that they lose their "ethnic" designation but are still consumed on par with other "ethnic" foods (Gabaccia 1998).

Diner (2003) delves deeper into the particularities of certain ethnic identities around food and how they were connected to the particular experiences and histories of immigrant groups in the Old World and their new experiences in the U.S. Diner compares Italian, Irish and Jewish immigration to the United States from the mid-1800s to the 1920s. In the case of Italians, Diner argues that they were able to forge a national identity behind food in the U.S. to underplay the regional and class distinctions amongst themselves that were widespread in the Old World. The Irish immigrants on the other hand were not able to use food in this way because their food traditions were too closely linked to the Great Famine. Finally, Diner argues that Eastern European Jews, like Italians, also made food part of their ethnic identity in the U.S. and the availability of nonkosher and kosher foods was an important issue in the struggle over keeping traditional foodways and assimilating.

Although Diner provides more nuance and contestation over the idea of a melting pot in the U.S., there is still, as in the case of Trinidad, the issue of inclusion and exclusion of indigenous identity. Popular discourse and politics on multiculturalism may be inclusive to many immigrant groups but an "immigrant nation" invisibilizes the presence and struggle of Native Americans. As Siskind (1992) suggests:

In odd contradictions of mythic thought, recent immigrants may ritually become Americans, and their children will eventually be considered 'native-born Americans,' but Native Americans, the earliest immigrants to the continent, are excluded from this imagined community. As America has continued its 
imperialistic civilizing mission within and beyond the borders of the United States, the construct of 'natives' as non-human has incorporated many others. (Siskind 1992, 182)

Although the U.S. melting pot may grow to include new immigrant groups, indigeneity holds a problematic place in the national imaginary which can be better understood through the examination of food and food consumption. Siskind analyzes Thanksgiving as an invention from the nineteenth century that is "purely American." Siskind contends that Thanksgiving is a time that brings family members together and reaffirms kinship bonds in an "aura of region and patriotism" where the Thanksgiving turkey is a central symbol of the American ethos (Siskind 1992, 168).

According to Robertson (1980), the turkey represents Native Americans that are sacrificed and consumed for the creation of the New World by a Puritan population that sees itself as the chosen people who shall conquer the wilderness and impose civilization. Siskind reveals many parallels between the way the bird is treated and incorporated into the Thanksgiving holiday with the perceptions of Native Americans in U.S. culture. In the 17th century, "the co-occurrence of wild and domesticated birds makes a perfect metaphor for Native Americans," since at the time there were also Indians who were perceived as wild enemies to be respected yet also killed, and domesticated Indians who converted to Christianity and became "civilized" $(1992,179)$. As such, Siskind explains that "as a true 'native of America' the turkey, wild and domesticated, could easily become a symbol for those other natives, constructed not as Americans but as Indians - others" $(1992,179)$.

While Gabaccia (1998) proposes the melding of different ethnic foods to understand U.S. nationalism as a "polyglot culture," Siskind (1992)'s analysis of the Thanksgiving turkey shows how U.S. nationalism is predicated on the exoticism and consumption of the indigenous Other. 
In fact, indigenous rights and foodways have an important place in any analysis of nationalist projects. Colonial powers invisibilize and marginalize indigenous populations to justify displacement and resource extraction. As Siskind argues, certain cultural practices and symbols were appropriated for the sake of the national imaginary and continue to impact issues relating to indigenous land rights, political representation, and intellectual property.

\section{The Food Movement}

The rise of the nation-state and modernity analyzed by previous scholars has also given rise to fear over cultural loss, religion, and a complicated relationship with the environment. Further, rapid industrialization starting in the late 1800s created economic, labor and social conditions for urbanization, rural depopulation, and class distinctions. In particular, the industrialization of food production displaced small farmers and distanced consumers from producers. The development of the global economy exacerbated these effects and the fears and anxieties about life in the modern world. As a result, resistance towards these processes has taken different forms. The food movement aligns with other movements in questioning current production, processing, and consumption patterns. In a collection of works Counihan and Siniscalchi (2013) present how these different types of food activism or "diverse forms of dissent and resistance" function to change factors of the food system to varying degrees $(2013,7)$. The fears and anxieties of modernity and industrialization have made people question what they eat, where their food comes from, and why they eat it.

The actors, ideas, and actions taken in these movements are diverse. These responses range from individualistic (veganism to ethical consumption) to collective (building alternative solidarity economies). While some aim to completely upend the globalized food system others 
seek more transparency in production processes. Counihan and Siniscalchi (2013) underscore that there is a great range of ideology and scalability:

Some movements, like Slow Food, highlight a conception of food democracy defined as universal access to tasty, healthy, sustainable, and fairly produced food, whereas others like La Via Campesina, emphasize food sovereignty and its focus on local control of food production and distribution. $(2013,9)$

In these different movements, it is clear that food has become a center piece of conversation for many other issues. As discussed earlier with Boisard (2003), at the center of French identity is a means of communication for issues of urbanization and loss of traditional foodways. As such, some activists aim to tackle the inequities rooted in the neoliberal, industrial, global food system.

Some scholars have remarked that the food movement may help indigenous groups claim political authority or recognition within the nation-state. Wynberg (2017) for instance comments on how the San and Khoi tribes of South Africa have claimed intellectual rights on South African biodiversity. Because of marketing strategies that aim to connect consumers with producers to appeal to some of the concerns of the food movement, many companies feature indigenous or peasant people on their packaging. Legal claims from the San and Khoi tribes of South Africa have forced companies like Nestle to give a portion of their profits on their sales of rooibos - a tea that has gained popularity through the food movement for its health properties and ability to cure headaches, hypertension, allergies, and premature aging.

Perhaps in the spirit of these strategies, food scholars have employed a "follow a thing" approach to understand how specific food items traverse through time and borders to mean different things for different people and to gain a deeper understanding of the distances (geographical, economical, and cultural) between sites of food production and sites of consumption. Nationalism, ethnic identities, and especially indigenous rights are central to these 
analyses as consumers who make up the movement are increasingly interested in the "real" origin of the food they are consuming and the people who produced it.

Pilcher (2017) embarks on a journey to find the "authentic carne asada tacos" in Hermosillo, Sonora and is confronted with many of the complicated dynamics involved in the creation of national foods and globalization. Authentic Mexican food has been redefined and contested by several different actors in the last two centuries. Pilcher traces the history of these contestations among indigenous people and creoles, Mexicans and Mexican-Americans in the United States and between different regional varieties within Mexico versus the urban cosmopolitans. On the one hand, more recently, American transnational food corporations have appropriated certain ways to make tacos which has also redefined Mexican food within Mexico and throughout the world. In this way, Pilcher shows how Mexican food was first globalized through colonization which brought maize, chocolate and chiles to the Old World. Further, Mexican food is represented in three different ways including an indigenous, creole and commercialized form. Interestingly, Pilcher (2017) shows that Mexican food in its commercialized form by large corporation in the United States has globalized Mexican food as a variant of American food. And as other studies on national foods highlight, class and ethnic distinctions and politics were integral to the development of Mexican national food. In the nineteenth and early twentieth century, both Americans and Mexican elites viewed Mexican street food like tacos as unsanitary and unhealthy. Pilcher (2017) draws attention to how in the nineteenth century, Mexicans debated if the national cuisine should in fact include indigenous and creole foods or if it should look to French haute cuisine since these indigenous foods symbolized unsanitary and backwards conditions. 
Pilcher's (2017) recount of these early discussions that formed Mexican cuisine are especially important in understanding the food movement, globalization and nationalism today because his analysis highlights some of the key tensions and problems with the movement. Juxtaposed with those nineteenth century attitudes, Pilcher points out that today Mexican cosmopolitans and culinary elites stand in opposition to commercialized Mexican food by claiming that authentic Mexican food lies in peasant and indigenous dishes that were previously perceived as uncivilized. In this way, indigenous foods today are often used within the food movement to bring authenticity and legitimacy to production sites. Similarly, Pilcher (2008) delves deeper into this point by critiquing the Slow Food movement more directly and showing how it "bears more than a passing resemblance to the mission civilisatrice of nineteenth-century imperialism" $(2008,407)$. While the marketing in the foods of the slow food movement proclaim to empower indigenous people or "village women" the profits tend to stay with intermediaries rather village people or village cooperatives as he illustrates with the example of Tia Tana Chocolate $(2008,407)$.

It is important to ponder, then, how these emerging marketing strategies as a result of the food movement affect producers and/or the groups being depicted on these labels. Is it enough for a company like Nestle to pay a small percentage of their large profits to the groups they choose to feature on their products? If so, such an agreement still accrues a lot of profit for Nestle and places power in the hands of consumers who will or will not be persuaded to buy Rooibos that features the San and Khoi people. The changing perspectives of food have created a new phenomenon where foods like rooibos are vindicated by the food movement as a "superfoods" and are attractive to consumers in the Global North who are sympathetic to the broader concerns of the alternative food movement. 
Loyer (2015) describes superfoods as an important phenomenon of the food movement because they are "understood both as a discourse about food and health and a group of agro-food products, they offer a distinctive lens through which to conceptually bring together geographically (and, often, socioculturally) distant worlds of production and consumption." Loyer (2015) follows maca root from the shelves of health food stores in Australia to growers in Peru where maca forms part of the livelihoods of people in the Junin and Pasco regions as well as forming part of Peruvian national identity. Furthermore, maca has been legally designated under the national intellectual property organization IDECOPI $(2015,11)$. Although this designation and its incorporation into the national cuisine has helped local growers, Loyer (2015) acknowledges that its advertising to Western consumers as an indigenous product exoticizes producers in well-known historical processes of imperialism.

In some cases, indigenous people have been able to leverage some consumer support for their own rights, while in others these groups have been further invisibilized or profits and benefits have been absorbed by intermediaries as in the case of Tia Tana Chocolate. These cases took me to research not only how yerba mate became a national symbol and how it is currently talked about in marketing and popular discourse in Argentina but also how its entrance into the United States as a health food has created new narratives that speak to indigenous issues because of the concerns of Northern consumers. In the following chapters, I delve into yerba mate's past in Argentina and analyze present symbols and discourse which, as I argue, reinforce yerba mate's role as a national food in Argentina and transform yerba mate into a superfood in the United States. 


\section{CHAPTER I: THE WHITE YERBA MATE NATION}

Although the extent and purpose of yerba mate consumption by pre-Hispanic Guaraní is debated among scholars, most ethnohistoric evidence suggests that European colonizers learned production and consumption techniques from the Guaraní indigenous inhabitants of the region whom they also exploited for labor (Albes 1916, 8). These techniques continued to be used when the Jesuits discovered how to germinate the plant and grow monoculture plantations (Crocitti 2002, 3-15). The yerba mate plant can typically be harvested after four years of growth from seed (Folch 2010,9). Producers cut the top of the tree branches and expose them to direct fire for 20-30 seconds to stop the leaves' oxidation in a process called sapecado. After this, the leaves are dried indirectly in a process that the Guaraní originally called barbacua and is now called secado (Crocitti 2002, 9). Depending on the finished product desired, the branches and leaves may be separated or kept together when grounded. The resulting product is called yerba canchada and is popularly consumed in Brazil. In Argentina and Paraguay, the yerba canchada is aged for six to twelve months until it acquires a yellowish color and slightly more bitter taste.

The production and consumption of yerba mate grew extensively in South America during the colonial era as various colonizers engaged in its production through the exploitation of the indigenous Guaraní. In this way, and through many social and economic processes I discuss later, yerba mate production and consumption became widespread. Today, Argentina and Brazil are the biggest producers of yerba mate in the world (Rau 2008). About 90 percent of Argentine yerba mate is produced in the northeastern province of Misiones and the remaining 10 percent is produced in its neighboring province to the south, Corrientes (Rau 2008, 1). Further, most of this production fulfills domestic demand while only 10-15 percent of production is exported to the other South American countries and the Middle East (Rau 2008, 1). 
Any visitor to these yerba mate consuming countries will notice yerba mate's constant consumption across social and economic demographics (Millman 2013, 20). Because of its widespread and everyday consumption, yerba mate is deeply rooted in people's social world and identity (Millman 2013, 21). Thermoses and yerba mate gourds often showcase personalized designs. As Millman (2013) explains, the graphics on thermoses can include "...scenic agricultural landscapes with traditional Paraguayan harps and guitars... others are more contemporary, boasting illustrations of popular television and movie characters, or in bright colors and designs" (Millman 2013, 21). In Paraguay, Millman is offered a mate gourd as an authentic symbol of Paraguayan culture (Millman 2013, 20).

Just as Millman is offered a gourd in Paraguay as a symbol of Paraguayan culture, many newcomers to these areas are often directed to yerba mate as something that is quintessentially part of social customs. On April 2, 2018 La Nación published an article titled, "Córdoba: the program that explains cuarteto and mate to foreign exchange students."4 Figure 2 shows the photo published under the headline that opens the article. A young woman sits crossed-legged with a group of other young people in a park. She is holding a mate gourd and smiling, La Nacion's caption reads, "Foreign exchange students are integrated through mate" (Figure 2). The article highlights a student-led program where local students "hope to integrate foreigners who are on exchange or are regular students. Once a week in open and voluntary events, they come together to talk about topics related to their classes, cuarteto, history of the province and traditional foods." 5

\footnotetext{
4 "Córdoba: Cómo es el programa que les explica el cuarteto y el mate a los estudiantes extranjeros."

5 "Es un programa impulsado por los propios estudiantes hace cinco años y que apunta a integrar a los extranjeros que cursan intercambios o son alumnos regulares. Una vez a la semana -en juntadas abiertas y voluntarias- se reúnen y charlan desde aspectos del cursado hasta de cuarteto, historia de la provincia y comidas típicas."
} 
The student coordinator remarks that they had great attendance at their first meeting which was a "mateada al aire libre" meaning a mate drinking get-together outside. The photos in the article are solely from this mateada. It is interesting to highlight that the students were interviewed about many other events and outings where they explored the city of Córdoba, went dancing, or held asados, however the students pick the mateada as their first meeting and this newspaper article specifically features mate in the headline even though the event is one of many. This highlights the importance of mate for both the locals and the author of the article. It is also important to know that mateadas among large groups of young people in plazas and parks are usual sights in cities throughout Argentina. Further, there are statements from students about yerba mate throughout the article that position them into local popular discourse on yerba mate. In one passage, a student from Rio de Janeiro explains that they hope to learn to "cebar mate" (serve mate) and the author of the article clarifies in parenthesis that the student "drinks it bitter and didn't like tereré." In another passage featuring another student from Brazil, the student remarks that it was surprising to see people drinking mate sweet or cold with orange juice instead of water. The program and this media response demonstrates the cultural and symbolic significance of yerba mate. 


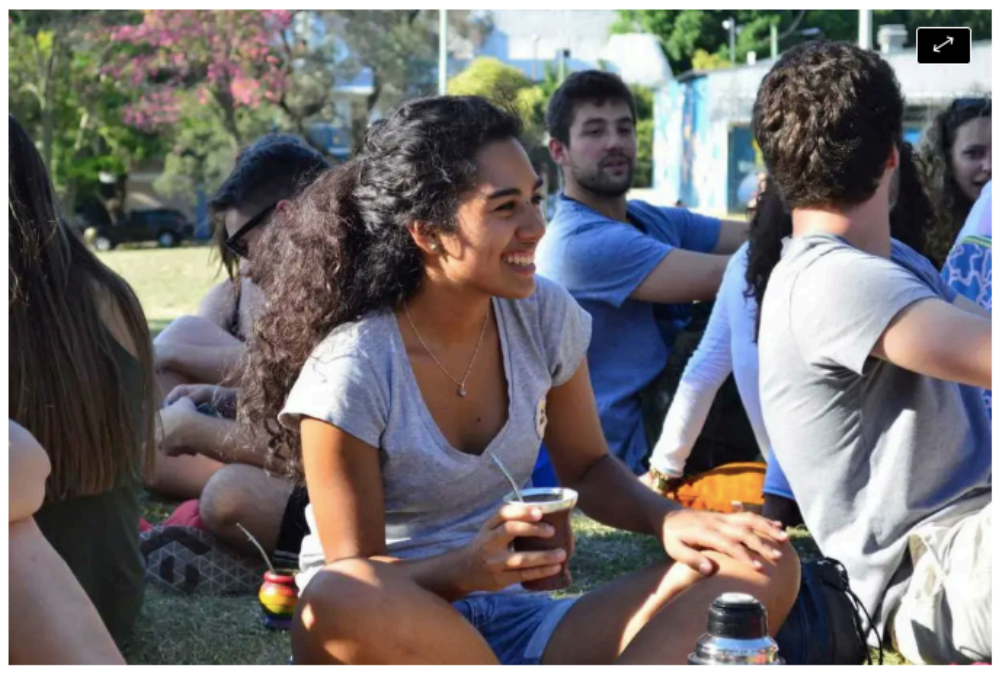

Los estudiantes extranjeros se integran a través del mate Fuente: LA NACION

Figure 2. "Foreign exchange students are integrated through mate." Retrieved September 19, 2018 from https://www.lanacion.com.ar/sociedad/cordoba-como-es-el-programa-que-lesexplica-el-cuarteto-y-el-mate-a-los-estudiantes-extranjeros-nid2121995

In Argentina, the population consumes large quantities of the yerba mate infusion, averaging 100 liters per person per year. ${ }^{6}$ Although yerba mate is very popular in the Southern Cone, its symbols, methods of production, and consumption differ in different countries and, even different regions within the same country. Here I focus specifically on yerba mate discourse in Argentina because of my own background and previous research but also because Argentina is one of the largest producers and consumers of yerba mate in the world (Gortari 2007, 21-31). In fact, according to the National Institute of Yerba Mate, yerba mate has a market penetration of 95 percent with about 70 percent of people consuming yerba mate regularly. ${ }^{7}$ Furthermore, Taragüi, the yerba mate brand examined in this study is not only the most popularly consumed yerba mate

\footnotetext{
${ }^{6}$ Retrieved from: https://www.lanacion.com.ar/sociedad/los-argentinos-tomamos-mas-mate-queagua-nid1960640

${ }^{7}$ Stated by Copoli, INYM official, here: https://misionesonline.net/2017/11/09/desde-inymrespondieron-los-dichos-la-chetadenordelta-fue-la-gente-la-salio-defender-mate-identidad/
} 
brand in Argentina, but the company that produces it, Las Marias, is the one of the largest producers of yerba mate in the world. As such, the company controls about 45 percent of the Argentine market and it is one of the four companies that controls 80 percent of the yerba mate market in Argentina (Ballvé 2007, 11).

Las Marias and other yerba mate companies came to exist in what is now the northeast Argentine provinces of Misiones and Corrientes through a concerted effort by the Argentine government to colonize the region and grow the national economy through yerba mate production and consumption. The issues in the yerba mate commodity chain within Argentina are multiple and complex. The growth of the yerba mate sector has contributed to vast deforestation since the early twentieth century. Further, the history of the yerba mate sector consists of unstable socio-economic conditions plagued with issues of child labor, unfair labor practices, land consolidation, racial segregation, and the murder and disappearances of labor organizers under the dictatorship of the 1970s (Galafassi 2005, Gortari 2007, Loyer 2016).

On the other end of the commodity chain, Argentine consumers are not always aware of these issues or yerba mate's complicated history. However, it is not my aim here to speak directly to consumer perceptions or beliefs, instead, I analyze the symbols surrounding yerba mate to understand what parts of this complicated history are being highlighted, re-imagined, or hidden. As I will show by examining Taragüi marketing and yerba mate history, yerba mate has been a signifier for different social positions and understandings of what it means to be Argentine.

In other words, although the Argentine state has had an economic incentive to promote the production of yerba mate, its consumption has not always been idealized. From indigenous substance, to royal tribute, to rural folklore, and national symbol, yerba mate has occupied 
different understandings within the Argentine imaginary since the founding of the country. In this chapter, I delve into deconstructing the contemporary discourse of yerba mate in the media and marketing as a national symbol by situating it within a historical framework and analyzing the economic and political implications of the discourse. I take a closer look at Las Marias and Taragüi marketing and thread themes in popular discourse with historical political and economic developments that shape the grand social narratives of yerba mate. I particularly shed light on the continued subjugation of indigenous people in the production of yerba mate and, in turn, in the Argentine national imaginary.

\section{Argentine Yerba Mate Territory}

In the seventeenth and eighteenth centuries, yerba mate was the sole and most important commodity produced in the Paraguayan province under Spanish rule. It was produced by indigenous Guaraní of the region in Jesuit reductions and under an encomienda system managed by Spanish settlers (Lopez 1974, 493). In the encomienda system, a system of tribute payment, indigenous people were forced to relocate to the swampy yerba mate groves during certain parts of the year to harvest leaves which were then used as a form of currency and shipped throughout the Spanish empire (Lopez 1974, 494). Through the encomienda system, the Spaniards made great economic gains from the widespread popularity of the drink, while the Guaraní suffered from the life-threatening conditions of harvesting yerba mate in the swampy Atlantic Forest (Gortari 2007, Lopez 1974).

In competition with the Spaniards north of the Tebicuary River (present day Paraguay), the Jesuit missions between the Tebicuary River and Uruguay River (southern Paraguay and the Argentine province of Misiones) learned to germinate the yerba mate plant and offered safer 
working conditions in large plantations (Gortari 2007, Lopez 1974, Smith 2014). These techniques were especially successful in increasing yields, which made consumption flourish throughout the Southern Cone in the seventeenth and eighteenth century (Smith 2014, 15). Yerba mate was sold and consumed in Buenos Aires and Montevideo, but also in Chile and even Peru (Folch 2010). However, when the Jesuits were expelled from South America in 1767, these methods left with them, creating a greater dependence on the forest harvesting methods of the encomienda system (Lopez 1974).

In this way, yerba mate was an important commodity in the colonization of this South American region and the subsequent devastation of the Guaraní communities (Rau 2008). It continued to be an important commodity after the War of the Triple Alliance that decimated the Paraguayan economy causing Paraguay's loss of its monopoly over the yerba market and setting up Argentina and Brazil to increase their yerba production (Lopez 1974, 509). As a result, yerba mate was an integral part in the formation of the national imaginary of these nascent states. Both Argentina and Brazil annexed land from Paraguay after the war. What is presently the province of Misiones, nestled in between Paraguay and Brazil, became strategically important for Argentina. Between the nineteenth and twentieth century, the production of yerba mate was fostered through Argentine state policies that aimed to solidify the province of Misiones as part of Argentina in a policy that Rau calls an "agricultural colonization" $(2008,1)$. The indigenous population living in the region was ignored and pushed out of viable agricultural land (Bartolomé 2004). With better technology, this state-run campaign revived yerba mate plantations and fomented the national production of yerba mate by selling small plots of land in Misiones to European settlers starting in the 1920s (Schiavoni 1998). This policy was part of a larger debate at the time to modernize and civilize the country. In 1876, the Immigration and Colonization 
Law was passed and offered immigrants food, lodging, transportation, and lands in the interior. In this way, the law promoted the colonization of the provinces and increased immigration to Argentina dramatically into the early twentieth century. The motivation behind this law was to whiten the population. As McGee Deutsch (2016) points out this process involved discussing and negotiating the whiteness of Jewish immigrants as well as immigrants from Southern Europe and the Mediterranean. Legislators and elites at the time spoke especially favorably about immigrants from Northern Europe (McGee Deutsch 2016, 46).

In the Misiones and Corrientes region, the incoming European families were given land for free and sold additional land under the agreement that they would use 25 to 75 percent of their land to plant yerba mate (Rau 2008, 8). Through this policy, the Argentine state set the stage to become one of the largest producers of yerba mate in the world.

Furthermore, the state was able to solidify Argentine national identity in a region that at the end of the nineteenth century was populated by indigenous people who had little attachment to any of the national projects of the area and whom the state had no interest in integrating into the national narrative (Rau 2008, 12). The policy allowed the unity of European immigrants from varied nationalities under the common purpose of yerba mate production, accompanied by the promulgation of a common language and educational institutions that assured a sense of Argentine identity among their descendants (Bartolomé 2004, Rau 2004, Schiavoni 1998). With state support, yerba mate production and consumption flourished in this region, becoming a central part of "misionero identity -- a source of livelihood, historical memory, and cultural reference" (Smith 2014, 18). Specifically, the immigrants who settled refer to themselves as “colono misionero" (Bartolomé 2004, 239). The varied nationalities of the immigrants included German, Polish, and Ukrainian, as well as French and Swedish (Bartolomé 1974, 240). This 
immigration policy and land expropriation is reflected today in the makeup of the yerba mate sector.

During Bowles (2013)'s ethnographic research in Misiones she notes that, "for the outside eye, there is a stark difference in who is farmer and who is laborer, i.e. farmers are largely white and of European descent while laborers are mostly brown-skinned criollo workers" $(2013,5)$. The indigenous population in the region was not erased, but instead dispossessed from their lands and continue to be oppressed and used as labor under new white colonizers. Throughout Argentina, indigenous populations that survived the massacres of the military campaigns known as the "conquest of the desert" continue to live today with little protections. It is within this colonizing process that the Navajos family acquired the land in which Las Marias stands today. The creation of their yerba mate brand illustrates some of these components and especially underscores the territorial expansion of the Argentine nation-state.

\section{Las Marias Company Profile}

The yerba mate company Las Marias is an agroindustrial venture located close to the small town of Gobernador Virasoro, where most of its workers live, in the northeast part of the Corrientes province close to the Misiones border. Las Marias is owned by the Navajas Artaza family who acquired 10,000 hectares of land in this region at the end of the nineteenth century (CELS 2015, 277). Victor Navajas Centeno started planting yerba mate on the land in 1924 when he inherited a portion of it from his father. By 1930, the company had started to produce its first yerba mate harvest (CELS 2015, 277). In these beginnings, their customers were mainly confined to the Corrientes and Misiones region until they obtained a truck for transportation to major Argentine cities where yerba mate was already commonly consumed. In the 1940s, Las 
Marias installed its own drying mill and integrated all levels of production giving it a major advantage in the market and becoming the only drying mill in the region. Small neighboring growers were dependent on Las Marias for their yerba mate processing (CELS 2015, 277).

The 2015 report from Centro de Estudios Legales y Sociales (CELS), an Argentine organization for human rights, states that Las Marias engaged in strategies to evade government regulations restricting overproduction. The regulations were established and regulated by a government agency called the Comisión Reguladora de la Yerba Mate (CRYM) which was founded in 1935 to protect small yerba mate producers by reducing land consolidation, controlling overproduction and therefore, prices. One of the main strategies taken by Las Marias, as described by the CELS report, was to break up their land into small plantations that abided by CRYM regulations and give ownership to trusted employees and close partners (CELS 2015, 279). In this way, Las Marias continued to grow even under regulations from CRYM. When CRYM was abolished in 1991 and a mass exodus of small farmers ensued, Las Marias was further benefitted.

Yerba mate from Las Marias was packaged and advertised solely under the brand "Taragüi" until 1980 when they decided to diversify their products with new product lines. They launched the brand, "Union," a more economic yerba mate blend with a softer taste. As the company has continued to expand, they have released new products and expanded their markets. In the 1950s, Las Marias also started producing tea (sp. Camellia sinensis) and in 1960 they started exporting their products to the growing yerba mate market in the Middle East. ${ }^{8}$

Today, Las Marias continues to play an important role in the yerba mate sector in Argentina. Its yerba mate is grown in monoculture plantations to increase yields. The company

\footnotetext{
${ }^{8}$ See Folch (2010) for a discussion of yerba mate consumption in Syria.
} 
has several different product lines. While Taragüi is the most popular, Las Marias also offers, "Union," "La Merced," and "Mañanita." As described by Las Marias on their website, these different brands vary in flavor because they are different blends of yerba mate from different regions of Corrientes and Misiones or because some contain more or less stems or powder, and/or because of differences in accelerated versus natural processing. ${ }^{9}$

As such an important force in the yerba mate market, Las Marias' products and its marketing are especially important to examine when understanding why and how yerba mate has come to be a signifier for the Argentine nation-state. However, before looking at the Taragüi marketing more specifically, it is important to first understand how the Argentine state and the Navajos family came to acquire the land in which Las Marias stands today.

\section{Taragüi: La preferida por los Argentinos}

The Taragüi yerba mate product labeling exhibits a strong connection between yerba mate production, misionero regional identity, and Argentine nationalism. In Figure 3, the Taragüi product labeling shows no information on consumption because it is such a widespread social practice that the knowledge is assumed (Millman 2013). Instead, the package includes general information about the production process. The text on the top simply tells the consumer that this yerba was made with the "palo" or the stems of the yerba mate plant and that it went through the drying and resting process. The text at the bottom of the package details where the yerba was made and therefore says "Establecimiento Las Marias: Virasoro, Corrientes," "Industria Argentina," and includes the weight of the package. The blue image in the middle of the package

\footnotetext{
${ }^{9}$ See product details here: http://www.lasmarias.com.ar/esp/detalle.php?a=tarag\% $\% 25 \mathrm{FCi}---$ produccion-yerba-mate $\& \mathrm{t}=7 \& \mathrm{~d}=28 \& \mathrm{n}=23559$
} 
reads "Taragüi," the brand name, which is set on an outline of the yerba producing province of Corrientes. This product labeling mainly emphasizes where the yerba mate was made. Every time a consumer picks up this package of yerba, the most prominent symbol directs the consumer to where the yerba was made. Its reference to the region gives the product authenticity by connecting the Argentine territory with the production and consumption of yerba mate.

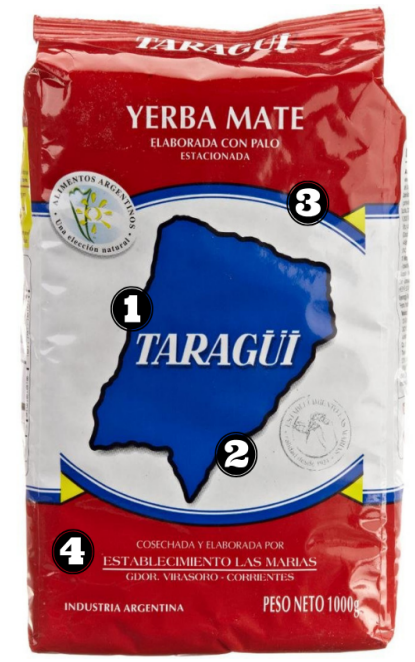
(1) "Taragüi" is a Guaraní word meaning lizard, used to refer to the capital of Corrientes. The name reaffirms a connection to land and place.
(2) Outline of the yerba mate producing province of Corrientes. Reference to the region gives the product authenticity.
(3) The red, blue, and white color scheme is the same as the provincial flag of Misiones.
(4) General information about production place and process.

Figure 3. Analysis of Taragüí Product Label by Author. Label retrieved March 20, 2019 from https://articulo.mercadolibre.com.mx/MLM-668281557-yerba-mate-palo-22lbs-_JM?quantity=1

The brand name "Taragüi" is a word of Guaraní origin meaning lizard which was used to refer to the capital of Corrientes. When the city of Corrientes was founded the Guaraní people called the capital of Corrientes, city of lizards because of the abundance of lizards. The name stuck in popular discourse as a way to generally refer to the city (Sorg 2008). Although the brand name has Guaraní roots, this is the only word or symbol in the packaging that gives credence to Guaraní involvement. In this way, yerba mate marketing in Argentina is often devoid of any 
signs of indigeneity. Instead, the symbols and language in the marketing give much more importance to a connection with the land. This land, as I have outlined, was given by the Argentine state to European immigrants leaving indigenous communities with little claim over the land or yerba mate production aligning with a process of state-driven blanqueamiento or whitening of the Argentine national identity.

As Bartolomé (2004) explains, Indians were not Argentina's "problem," as the national mythology proposes that all Indians died and Argentine ancestors are gauchos of European descent. Anyone of Indian descent is considered Paraguayan and/or Bolivian, and not an authentic Argentine $(2004,6)$. Scholars have shown how state policies in Argentina continually denied the presence of indigenous groups (Bartolomé 2004). Rau (2008) specifically points out that one way of doing this was to sell or give land to European immigrants whose descendants would become the Argentine farmers and gaucho ancestors of the modern Argentine, whitening any indigenous past or present. Like in many other colonized lands, indigenous populations were pushed to arid lands. In Argentina, they were pushed outwards closer to national borders where the connection between indigenous populations in Argentina and a foreign Other would be further pronounced. Evidence of this can also be found in the Patagonia where the police, military personnel, and rural landowners of European descent refer to the Mapuche indigenous group of the region as "indios chilenos" or Chilean indians (Bartolomé 2004, 3).

Since Chile has a larger population of Mapuche people, some Argentinians use this as a way to delegitimize and deny Mapuche identity and political power within Argentina (Bartolomé 2004, 3). Because of this discrimination, many people of Guaraní descent hide their ethnicity by speaking Spanish and adopting criollo culture (Hirsch 2004, 84). Connection to the Guaraní language and culture is incompatible with Argentinianness and therefore people displaying 
Guaraní cultural traits are deemed Paraguayan (Bartolomé 2004). The reinforcement of a national imaginary of a country founded on European immigrants is apparent in the symbols displayed and those missing in Taragüi marketing.

The strong connection between yerba mate and the land that was expropriated is important for the marketing because it is the origin of the Taragüi brand. As I have mentioned, this connection with land, yerba mate, and identity is particularly strong in the region, but the marketing and discourse surrounding the Taragüi brand also positions it on a national scale. Las Marias' grew, defying regulations by the CRYM and then being further benefitted by the abolishment of CRYM in 1991 and the subsequent deregulation of the yerba mate market until the founding of the INYM on 2002. In Figure 4, the INYM highlights the Taragüi brand on their website calling it "the preferred yerba by all Argentines." INYM is the organization that currently regulates the yerba mate market and sets prices for the yerba mate harvest while promoting domestic and international markets (Lawson 2009, 40). It is also concerned with the overall marketability of Argentine yerba mate. In Figure 4, INYM also calls yerba mate drinking "an Argentine ritual" and emphasizes again that this brand "is the one that most represents Argentine customs." 


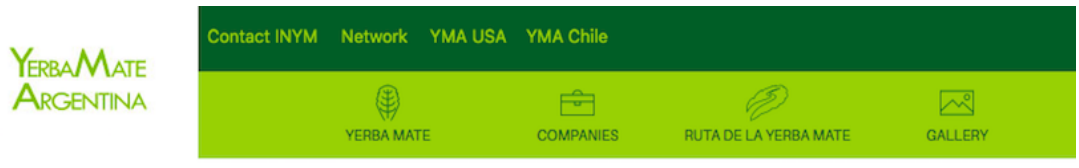
(ES) Es la yerba preferida por los argentinos. Ideal para preparar "mate", siguiendo los
pasos del ritual argentino.
Posee un blend impecable y noble, por su armonia entre cuerpo, aroma y madurez. Es la
yerba mate paradigma, y la que más representa las costumbres argentinas.

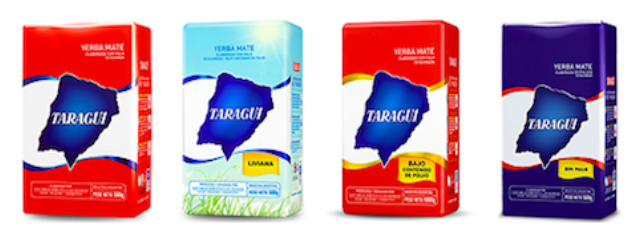

Te puede interesar:

$\star \star \star$ Taragüi: Agua gratis para el mate en todo el país $* * \star$

$\star * *$ Taraguí presenta su nueva campaña: Subíte al sabor. $* * *$

$\star \star *$ Taragüi presenta Saber Cebar, los secretos de un mate perfecto $* * \star$

Figure 4. Taragüi on INYM Website. Screenshot taken by author March 20, 2019.

However, the question of how Taragüi became the "preferred yerba mate brand for all Argentines" persists. The popularization of yerba mate consumption and its road to becoming a signifier for the Argentine state was promoted through state policies, but it was discussed and negotiated in popular culture and among elite literary icons since the country's independence from Spain.

As Ballvé (2007) states, the gauchos or the “mestizo cowboys of Argentina's rugged frontier days" popularized the consumption of yerba mate $(2007,10)$. In the early 1800 s, the gaucho was an archetype of popular culture that was of mixed Spanish, Indian, and African ancestry but whose racial make-up was "obscured by its becoming primarily a symbol that denoted the opposition between the city of Buenos Aires (associated with European immigration) and the hinterland of the pampas (associated with native traditions that were not normally cast as non-white)" (Goebel 2011, 37). As Goebel (2011) recounts, literary writers on Argentine identity in the 1880 s, saw the gaucho as the most significant symbol of national identity in reaction to the 
rapid modernization and immigration happening at the time. Goebel goes on to state that for writers such as Leopoldo Lugones and Manuel Galvez the gaucho became a symbol for antiimmigrant sentiments that glorified old customs of the pampa. However, the symbol transformed in the turn of the century as a group of urban intellectuals in 1964 started the journal Martín Fierro, as catalyst for later works in the gauchesca literature by Ricardo Guiraldes (Geobel 2011, 40). Geobel explains,

The racial mixing of which the gaucho was emblematic could be made compatible with a melting-pot imagery that was extended to immigrants, many of whom were themselves aficionados of the gaucho genre, thereby raising their credentials as 'true' Argentines. $(2011,40)$

As a result of these works, the gaucho archetype lost the earlier tones of xenophobia and was transformed into a national symbol that included new immigrants.

\section{Yerba Mate Argentina}

Since mid to late twentieth century, glorifying the gaucho and drinking mate were continually fomented as true markers of Argentinianness in popular culture as well as through government policies. One of the most recent actions to continue to foment yerba mate as a national symbol was in 2013 when the Argentine congress passed a law to officially declare

yerba mate as the national infusion. ${ }^{10}$ Shortly after this law was passed, Alejandro Federico Gruwer, the president of "La Ruta de la Yerba" an association of 200 yerba producing companies in Misiones and Corrientes (working with INYM), explained that declaring yerba mate as a

\footnotetext{
${ }^{10}$ Ley 26.871. (2013, July 30). Retrieved December 10, 2017, from http://www.boletinoficial.gov.ar/Inicio/Index.castle
} 
national infusion would help producers advertise Argentine yerba mate drinking outside of Argentina and tap into foreign markets. ${ }^{11}$

Furthermore, in 2016 INYM received a certification from the Argentine National Ministry of AgroIndustry for a Geographic Indication for Argentine yerba mate. ${ }^{12}$ Figure 5 illustrates INYM's Geographic Indication.

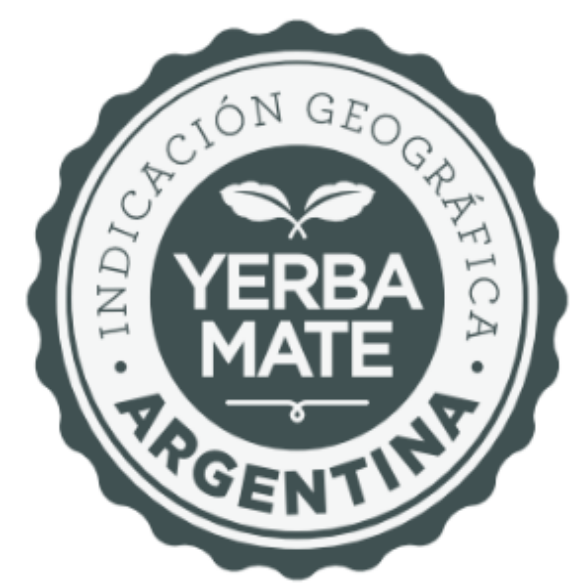

Figure 5. Geographical Indication Obtained by INYM. Retrieved September 19, 2018 from https://www.inym.org.ar/en/tag/indicacion-geografica/

Geographical indications (GIs) like the one obtained by INYM for Argentine yerba mate are protected under the Agreement on Trade-Related Aspects of Intellectual Property Rights (TRIPS) as an intellectual property right and are under the jurisdiction of the World Trade Organization (WTO). These are defined by TRIPS as "indications which identify a good as originating in the territory of a Member, or a region or locality in that territory, where a given quality, reputation or other characteristic of the good is essentially attributable to its geographical

\footnotetext{
${ }^{11}$ See statement here: https://www.americaeconomia.com/negocios-industrias/el-mate-buscaconquistar-nuevos-mercados-como-infusion-nacional-argentina

${ }^{12}$ Folleto INYM 2018
} 
origin." 13 In a memo about the new yerba mate GI posted on an Argentine Embassy website, the purpose of the GI is explained as follows:

...to provide legal protection and register the infusion born in our territory, whose consumption is rooted in the daily lives and the habits of millions of people at all socioeconomic levels and residents of the most recondite areas of the country. ${ }^{14}$

The GI serves multiple purposes. Firstly, it seems that the INYM is responding to the increasing likelihood of demand for yerba mate in the global market and attempting to distinguish Argentine yerba mate from its neighbors. Secondly, the GI also reinforces yerba mate as a signifier of the Argentine nation domestically. As I will also discuss later, these intellectual property right laws have been used in different ways by corporations, states, and indigenous groups to claim profits over certain food items. San and Khoi tribes of South Africa have claimed intellectual rights on South African biodiversity and forced Nestle to give up a portion of their profits on their sales of rooibos (Wynberg 2017). By certifying yerba mate as Argentine, the INYM and the state have invisibilized its indigenous background and instead, yerba mate is legally defined as something deeply Argentine.

As I stated previously, the gaucho and yerba mate drinking have symbolized the rural interior in opposition with the modernity of metropolitan Buenos Aires. Although yerba mate drinking is widespread and found across socio-economic status, it has also long been considered “'bread of the poor' for its relative cheap price as well as its properties for curbing hunger, it is a

\footnotetext{
${ }^{13}$ Article 22.1 of TRIPS

14 “A través de este sello que podrá llevar cada paquete de yerba mate (es opcional) se brinda protección legal y registro a una infusión nacida en nuestro territorio, cuyo consumo está arraigado en la vida diaria y en los hábitos de millones de personas de todos los niveles socioeconómicos y residentes de los puntos más recónditos del país." Retrieved from: https://eserb.cancilleria.gob.ar/es/content/indicaci $\% \mathrm{C} 3 \% \mathrm{~B} 3 \mathrm{n}$-geogr $\% \mathrm{C} 3 \% \mathrm{~A} 1$ fica-de-la-yerbamate-argentina
} 
staple food, forming part of the basic food basket alongside staples such as flour, oil and sugar" (Bowles 2013, 2).

The connection to low-income, rural people is not lost on elites who want to distinguish themselves from the populous. In November 2017, as La Nación and other major newspapers reported, in a WhatsApp audio message popularly shared in social media, an upper-class woman, Cinthia Solange Dhers, condemned the yerba mate drinking ritual. Dhers was a surgeon who had recently bought an apartment in the upscale neighborhood of Nordelta in Buenos Aires. ${ }^{15}$ She was disappointed by the neighborhood and sent her friend a voice message where she complained about how it did not meet her "moral aesthetics" and how her neighbors were "beasts, with no education, who yell and drink mate like they would at Bristol beach in Mar del Plata."

The audio was shared massively through social media and discussed in talk shows and newspapers with particular emphasis on yerba mate drinking as a low brow activity. As the La Nación article summarized, the social media posts mocked Dhers for the elitist remarks about yerba mate. In Playa Bristol in Mar del Plata, hundreds of people organized a mateada to protest the remarks made by Dhers. Even Las Marias interjected with a social media post (Figure 6) in which they emphasized the widespread consumption of yerba mate, and therefore Taragüi, from Bristol to Nordelta. They captioned the post, "yerba Taragüi, wherever... the mate is Taragüi" (Figure 6).

${ }^{15}$ See article here: https://www.lanacion.com.ar/sociedad/la-cheta-de-nordelta-fuerte-respaldoal-mate-en-las-redes-sociales-nid2080554 

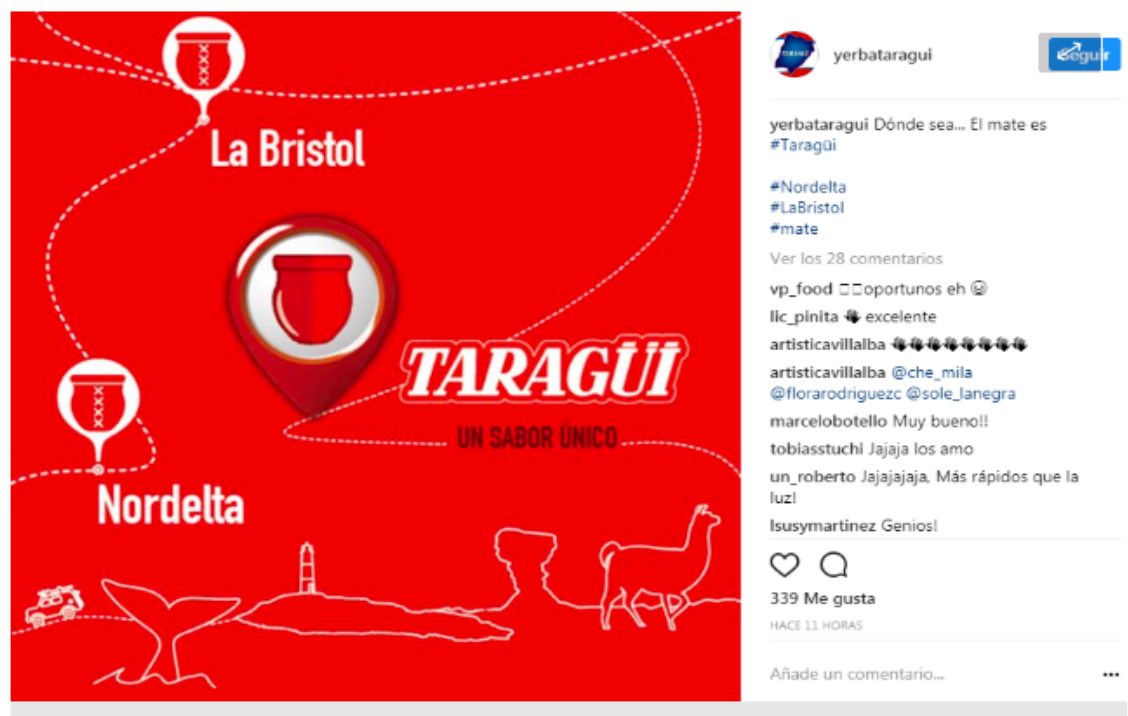

Figure 6. Twitter Post Made by Taragüi on Nordelta Incident. Retrieved September 19, 2018 from https://www.lanacion.com.ar/sociedad/la-cheta-de-nordelta-fuerte-respaldo-al-mate-en-lasredes-sociales-nid2080554

The strong backlash against Dhers reaffirms the importance of yerba mate in the Argentine imaginary. Promoting yerba mate as an Argentine symbol has served to expand the consumer base domestically. However, this position in the market also means that there is a strong need to keep the prices down. If the essence of being Argentine is connected to drinking yerba mate, then access becomes a highly political issue. While Taragüi marketing is heavily dependent on yerba mate's indexicality with Argentine nationality, networks of small producers and consumers have also been able to organize around these same principles to demand policy change in a consolidated market plagued with exploitation. In the following chapter, I explore how market instability and price volatility have sparked new movements and redefinitions of yerba mate symbols. 


\section{CHAPTER II: YERBA MATE OF THE RESISTANCE}

In the previous chapter on Las Marias, Taragüi yerba mate brand, I showed the ways in which the yerba mate production in the provinces of Misiones and Corrientes became strategically important for the nascent Argentine nation-state. The connection to land conquered and the invisibility of indigenous people was used to create an Argentine imaginary where the population was imagined as homogeneously white. The gaucho archetype was reimagined in the early twentieth century and also whitened as waves of immigrants from Europe used it as a way to assimilate and to prove their Argentinianness. In this way, although yerba mate may appear as simply a symbol of national identity, its history is filled with class and racial tensions that persist today. As a result, yerba mate is central to discussions of what it means to be Argentine as well as the social inequity and political struggles of the agricultural sector.

In this chapter, I examine the yerba mate brand, Titrayju, sold by the agricultural cooperative, Cooperativa Agrícola Río Paraná. This brand, often referred to as the "yerba of the resistance," was born out of a movement in Argentina that opposed the neoliberal economic policies of the 1990s that triggered the 2002 economic crisis. The cooperative played a crucial role in changing policies in the yerba mate sector to protect small farmers while also attempting to keep prices low for consumers.

\section{Cooperativa Agrícola Río Paraná Profile}

The Cooperativa Río Paraná was started in 1975 through the agricultural movement, Moviemiento Agrario Misionero (MAM) in the province of Misiones (Gonzalez 2017). This cooperative brings together 200 small farmers, averaging 5 hectares of land each, to produce

yerba mate and sell other goods in their ferias francas (Smith 2014, 63). Their headquarters are 
in Oberá, Misiones. Río Paraná started selling yerba mate in 2001 with a brand they created and named Titrayju, meaning "Tierra, Trabajo y Justicia" (land, work, and justice). At the time, the increasing economic instability meant that social networks and organizations had to come together to provide food and other important goods through alternative ways. One of these particular avenues was the ferias francas that MAM helped to organize in Misiones. Ferias francas are markets where small farmers can sell directly to consumers (Wharen and Gerreiro 2014,311 ). In the midst of the economic crisis of the early 2000s, ferias francas from Misiones became very popular throughout Argentina because they provided consumers with lower prices than the supermarkets but still gave farmers a fair rate of return (Smith 2014, 62).

Through ferias francas and the creation of Titrayju, MAM and Río Paraná created an alternative economy for yerba mate production. Today, Titrayju yerba mate is still sold in Misiones at ferias francas and in certain socially oriented markets or specialty stores in Buenos Aires and throughout the country ${ }^{16}$ (Ballvé 2007, 11). Río Paraná has refused to sell to supermarkets and instead partners with other cooperatives, and neighborhood and grassroots organizations. As Smith (2014) points out, by not selling to supermarkets, Titrayju can offer yerba mate at a significantly lower price $(2014,67)$. Gonzalez (2017) presents Titrayju as an example of an agroecological movement that has created a social and solidarity economy which brings together those marginalized by the broader economy with the goal of achieving food sovereignty rather than just a higher quality product like other organic food production.

In the production of Titrayju, Río Paraná aims to pay their farmers a fair price per kilo of yerba mate leaf while reducing intermediaries to still provide consumers an economic price for

\footnotetext{
${ }^{16}$ Where to find Titrayju: http://www.yerbamatetitrayju.com.ar/titrayju-puntos-ventas.html
} 
the finished product. ${ }^{17}$ They call their model and philosophy comercio justo. ${ }^{18}$ As Zarranz (2018) explains, the problem is that the large companies that control the market and have the technology for drying and milling pay small farmers far less for the green yerba mate leaves before processing. This not only creates problems for small farmers but also for tareferos who are in turn paid less for their labor (Zarranz 2018). In the case of Río Paraná, according to Smith (2014), most of the farmers do not hire tareferos and instead rely on family and communal labor for harvesting $(2014,64)$. Further, Río Paraná has tried to reduce their costs and intermediaries by purchasing a molino (mill) and packaging facilities. In a 2014 article from Misiones Online, a Minister from the Misiones Province speaking at the inauguration of Titrayju's molino called it "a dream come true" for the members of the MAM. ${ }^{19}$

Although their production techniques are organic because they do not accelerate the drying or resting processes (secado and estacionamiento), the cooperative has also refused to engage in seeking any organic or fair labor certification because they believe that these certifications should not have to be paid and create more administrative burden. ${ }^{20}$ The cooperative has also been working on supporting other products, for example, they started working with a small farmer who wanted to plant stevia and make a yerba mate and stevia

\footnotetext{
${ }^{17}$ Interview with Titrayju by El Colectivo al Margen. https://almargen.org.ar/2018/11/03/yerbatitrayju-del-productor-a-tu-mesa/

18 Titrayju Website: http://www.yerbamatetitrayju.com.ar/index.html

${ }^{19}$ Newspaper article on Titrayju molino: https://misionesonline.net/2014/11/26/quedoinaugurado-el-molino-de-yerba-titrayju-en-panambi/

${ }^{20}$ Interview with Miguel Angel Rodriguez in El Abasto, 2006:

https://original.revistaelabasto.com.ar/Titrayju.htm
} 
blend. ${ }^{21}$ Titrayju was the only organic yerba mate brand that would partner with the stevia farmer to develop the blend. Together, they developed "Dulce Misionerita" another brand sold through Río Paraná.

The model espoused by this yerba mate cooperative aims to foster an alternative economy where the small farmers of Misiones can subsist and thrive instead of having to sell their land and leave their farms contributing to the disappearance of rural life and the advancement of agribusiness and land consolidation. In this way, Titrayju has created a yerba mate brand and narrative that symbolizes the struggles of small farmers against capitalist exploitation. As such, like other products in the food movement, it aims to defetishize the commodity by visibilizing producers. However, in doing so, it continues to foment the idea of Argentina and Misiones as a white, European and homogenous society.

\section{Los Colonos y La Resistencia}

Starting in 1935 with CRYM (Comisión Reguladora de la Producción y el Comercio de la Yerba Mate), yerba mate production was regulated through a quota system that helped protect small and medium sized farms (Lawson 2009, 19). The CRYM was able to keep small producers viable through these policies even though, as I have noted, some companies like Las Marias found ways around the regulations. However, the yerba mate sector started to change in the 1950s as technological innovations were incorporated by farmers and promoted by CRYM. Yerba mate's increasing popularity and mass production in monoculture plantations combined with a thriving timber industry have contributed to deforestation (Cockle, Leonard, and Bodrati 2005, 3265-3288).

\footnotetext{
${ }^{21}$ Newspaper article on Maria Duarte's stevia and yerba mate blend: https://www.elterritorio.com.ar/la-historia-de-la-emprendedora-que-desarrollo-su-yerba-constevia-1109163617457105-et
} 
As explained by Lawson (2009), this created a change into commercial production that moved away from small-scale sustainable extraction to mass yield maximization. Therefore, the policy changes favored larger producers who could make capital investments to pay for machinery and agrochemicals $(2009,21)$. Lawson (2009) also notes that there was a cultural shift in farmers' perceptions of yerba mate in that they were not only pushing for higher yields but also began to "emphasize the importance of clean, weed-free fields. One farmer reported that there used to be competitions as to who had the 'cleanest, prettiest' yerba field, meaning that it was completely free of weeds" $(2009,23)$. This great shift worsened environmental degradation in the region and further entrenched the inequity between small and large producers.

MAM formed in 1971 but was disbanded in 1976 after the military coup. Many of MAM's members were targeted during the Argentine Dirty War. In Ballvé's (2007) NACLA Report on yerba mate the article opens by describing the chilling moment in which two members of the MAM, a father and his son, turned on their radios in the morning of March 24, 1976, and heard the Argentine military announce their takeover. Ballvé (2007) recounts the history of MAM and the rise of Titrayju connecting the social significance of yerba mate to the economic and political issues at the time. Kasalaba, the leader of MAM, and his father hear about the military coup over the radio and when Kasalaba becomes upset, his father responds with "Come, let's have a mate." Ballve goes on to state that through stories like this, we understand that yerba mate drinking is a "fixture of daily life," “...a chance to relax and socialize.” Ballvé (2007) also explains that when the coup happened, the military called for the arrest of the secretary general of the MAM. He was found mutilated months later $(2007,10)$. Deregulation continued to benefit large producers when in 1991, as Mercosur came into effect, Argentine President Menem eliminated the CRYM and deregulated the yerba mate industry. This policy change was in line 
with other agricultural changes at the times that increased industrial agriculture (Hocsman 2016, 8). This led to further strife for small farmers who now had to compete with yerba mate producers in Paraguay and Brazil. Wahren and Guerreiro (2014) explain that since the 1990s, the liberalization of the economy and the strengthening of agrobusiness has resulted in increasing social exclusion of small farming families in agrarian spaces $(2014,300)$.

The economic devastation of the region in the 1990s made it incredibly difficult for yerba mate growers. Consumer demand for yerba mate remained constant and without the quotas from CRYM, overproduction drove the price of yerba mate from 20 cents per unprocessed kilo in 1991 to 2 cents in 2002. As Ballvé explains, "a campesino with 25 acres could make about $\$ 10,000$ from the yearly mate harvest, but by 2001 the same yield garnered only $\$ 1,000 "$ (2007, 10). Since the province of Misiones is heavily dependent on yerba mate production, the whole province suffered as prices plummeted. Kasalaba explains to Ballvé that the devastation of their communities was worse than during the dictatorship (Ballvé 2007). Many small producers were run out of business and Kasalaba describes the situation as a "mass exodus" which led to four large companies controlling 80 percent of the yerba mate market.

MAM and the Cooperativa Rio Parana decided to launch Titrayju in 2001 at the time which ferias francas became popular as alternative markets to access food. Titrayju's main purposes were "providing a living to its members" while also trying to "make a minimal environmental impact through organic production and other eco-friendly farming methods - careful soil preservation, not cutting down trees, and traditional processing" to protect the biodiversity hotspot (Ballvé 2007, 11). The crisis also resulted in massive protests and solidarity networks throughout the country. Further, as Ballvé (2007) recounts, Titrayju was successful in its debut because it was quickly taken up by these social organizations and networks throughout the country and became known as 
the "yerba of the piqueteros." Piqueteros are protesters in Argentina that block the streets in mass demonstrations to call attention to unemployment or other issues. This form of protest continues today, but it came to rise in the 1990s. Because of the crisis and the rising social organizations, it was easier for Titrayju to be sold directly to consumers. For example, the Centro de Comercialización Campesina e Indígena (CECOCAI) became a principle point of sale for Titrayu in Buenos Aires. Ramón Martín Enríquez, a MAM member, tells Ballvé, "I guess you can say that with the 2001 crisis, Titrayju became fashionable. Social organizations appropriated it as a symbol" $(2007,11)$. The Cooperativa Río Paraná's struggles communicated through the name of their brand, "Tierra, Trabajo, y Justicia" (Land, Work, and Justice) resonated strongly with Argentina's middle and working classes after four-year recession with a 20 percent unemployment rate (Schamis 2002).

\section{From the Hands of the White Misionero}

In Figure 7, Titrayju's product labeling follows a simple design similar to Taragüí with little information on the packaging other than where it comes from, Oberá, Misiones. Titrayju highlights the nutritional and environmental benefits of its yerba mate (Figure 8). In this way, Titrayju attempts to distinguish its yerba mate from other brands and to appeal to a healthconscious consumer. However, unlike in the U.S., as I will discuss in the next chapter, the cooperative does not aim to solely provide a "premium" product for wealthy consumers. Instead, they often remark that they not want to make consumers pay more for the product. ${ }^{22}$

\footnotetext{
22 "Esas son las luchas nuestras, donde no queremos trasladar el precio al consumidor y al mismo tiempo tenemos que sostener a nuestras familias con este trabajo" in https://almargen.org.ar/2018/11/03/yerba-titrayju-del-productor-a-tu-mesa/
} 
Titrayju includes a sketch of a rural farming family in place of the outline of Misiones or Corrientes, as many other brands like Taraguí include. The text to the side of the sketch reads, "Producida y elaborada artesanalmente por los colonos y sus familias," meaning that it is handcrafted by "colonos" and their families (Figure 7).

\footnotetext{
(2) Titrayju stands for "Tierra, Trabajo, y Justicia" meaning Land, Work, and Justice. The brand is also known as the "yerba of the resistance."

(2) INYM stamp certifies quality and market standards.
(3) A romantic image of the supposed rural farming family producing this yerba mate.

4 "Handcrafted by colonists and their families." "Colonos" or
"colonists" are farmers of Northern and Eastern European origin or descent.
}

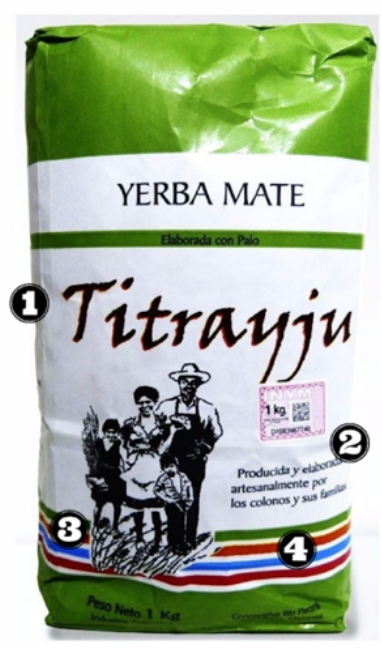

Figure 7. Analysis of Titrayju Product Label by Author. Label retrieved March 20, 2019 from https://articulo.mercadolibre.com.ar/MLA-645029728-yerba-mate-titrayju-agroecologica-1-kg- 


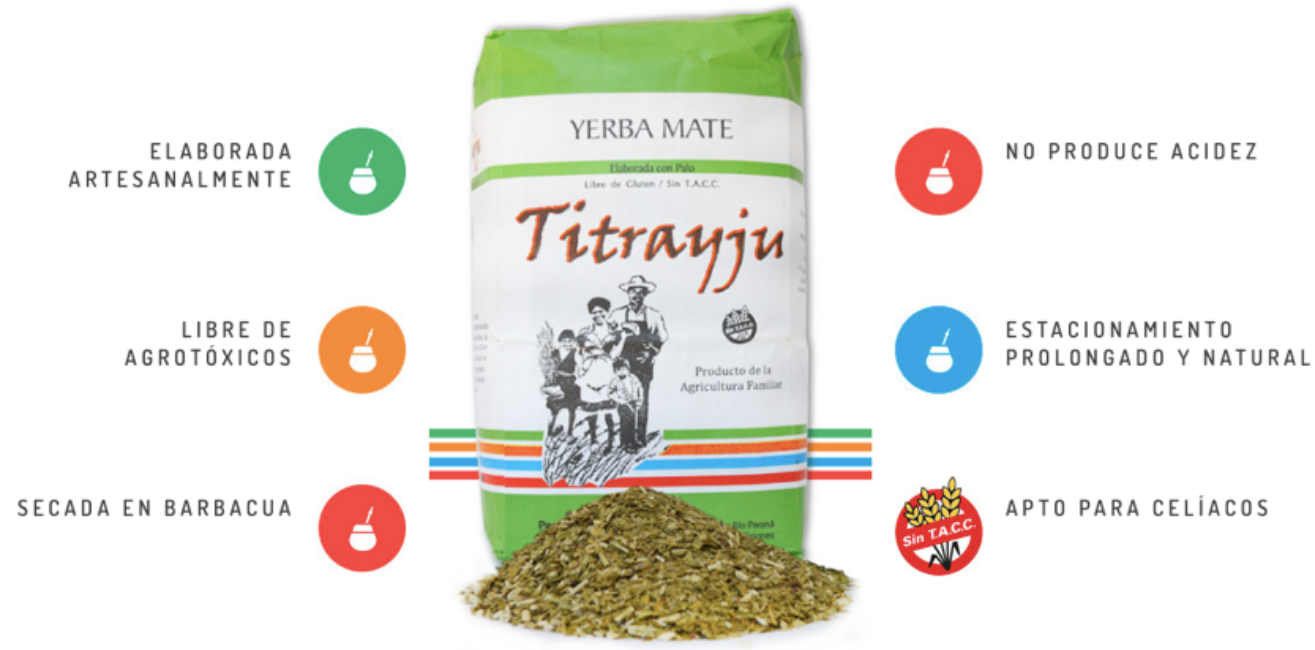

Figure 8. Titrayju Benefits. Retrieved September 19, 2018 from http://www.yerbamatetitrayju.com.ar/titrayju-yerba.html

Colonos refers to farmers of Northern and Eastern European origin or descent (Bartolomé 2004, 240). In an attempt to defetishize the product and to raise awareness of their existence and struggle, Titrayju highlights the colonos on their product labeling and in most of their marketing. Interestingly, on the Titrayju website, they provide a description of their struggle within the context of yerba mate production (see Figure 8 for their exact statement). Titrayju states that 80 percent of the population in rural Misiones is engaged in agricultural production and that 65 percent are small producers who are criollos or immigrant "gringos" (Figure 9). They go on to state that yerba mate was "historically the principal cultivar of the province" but they do not mention its indigenous or colonial past anywhere else in their website or product information. As mentioned, the packaging label mentions the "colonos" specifically but this statement on production also mentions "criollo producers." The use of the word "criollo" is important to breakdown for our understanding of the types of identities that are and are not being represented here.

As Pite (2016) explains that the term criollo has held many different meanings in Argentina and its ambiguity has shaped the constructed sense of Argentine racial homogeneity $(2016,118)$. 
In the colonial period, the term was used to refer to white, descendants of Europeans who were born in the Americas. It is clear that Titrayju does not use the term criollo to mean descendants of white Europeans because they instead refer to these particular people as "colonos" or "gringos" (Figure 7 and 9). Pite (2016) goes on to explain that the term criollo was also applied to indigenous people in the Northwestern Calchaquí Valley to relabel "Indians" into "criollos" $(2016,118)$.

\section{PRODUCCIÓN}

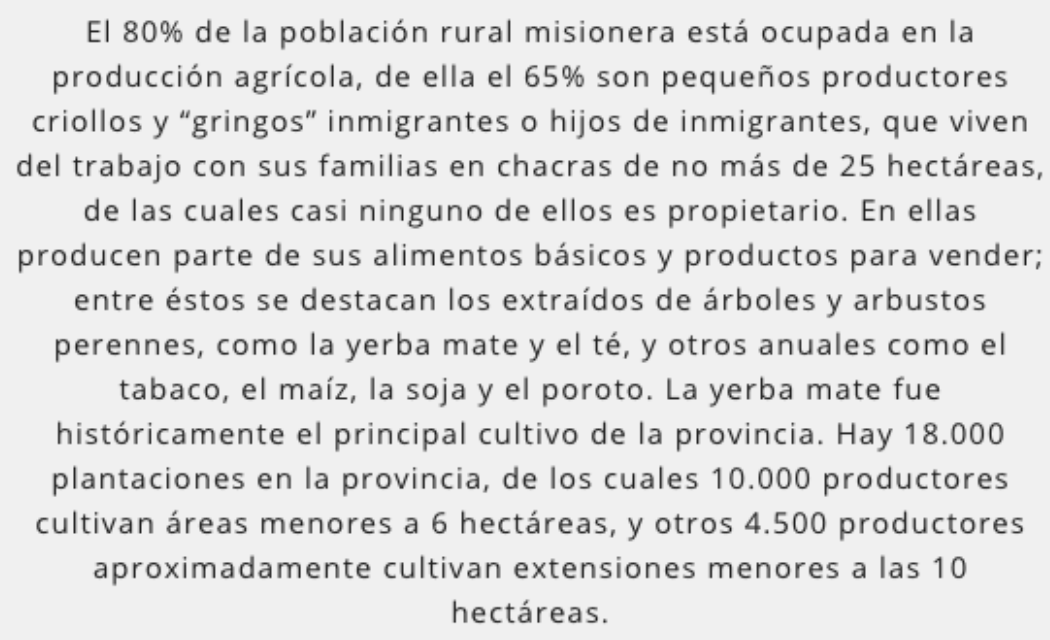

Figure 9. Titrayju Statement on Production. Retrieved September 19, 2018 from http://www.yerbamatetitrayju.com.ar/titrayju-nosotros.html

A Pagina12 newspaper article from 2003 describes the Titrayju brand and their "comercio justo" where Miguel Rodriguez, the Coordinator of CECOCAI at the time, is quoted saying that bringing Titrayju to Buenos Aires is a political decision to "bring the exploitation that is suffered in the farm into the city." 23 The article goes on to state that "red dirt, blonde Argentine descendants

23 "La llegada de Titrayjú acá es una decisión política, es traer a la ciudad la explotación que se sufre en el campo" stated by Miguel Rodriguez in https://www.pagina12.com.ar/diario/sociedad/3-26992-2003-10-19.html 
of colonos and yerba mate production are obligatory references of this place." 24 Even if all of the small producers that Titrayju works with are in fact immigrants or descendants of immigrants from Northern and Eastern Europe, bringing the exploitation to the city would mean discussing the complicated colonial history of yerba mate and the continued oppression of indigenous people. Although Titrayju's efforts through their marketing are helpful in bringing visibility to the struggles of small farmers in the face of agribusiness, the discourse continues to assert the construction of Misiones and Argentina as a "white" populous.

\section{Visibility for the Mbya Guaraní}

The social networks and protests that popularized Titrayju culminated in the creation of the Instituto Nacional de Yerba Mate (INYM). The INYM sets prices for the yerba mate harvest promotes domestic and international markets (Lawson 2009). INYM continues to regulate yerba mate production and struggles especially with the inequality in the region between the small producers, the larger producers of the region. Just as Titrayju highlights the colonos, the INYM also emphasizes certain actors over others. In its 2018 flyer, INYM includes a section that recounts the origins of yerba mate. It acknowledges that yerba mate was consumed by the Guaraní and continues to passively state that the Spanish conquistadors learned the uses and virtues of yerba mate. ${ }^{25}$ Without mentioning the slavery of the Guaraní under the Spanish, the text goes on to celebrate how the Spanish "made consumption flourish in an extraordinary way." ${ }^{26}$ Further, it states that the Jesuits were "responsible for making yerba known in the civilized world."27

\footnotetext{
24 "La tierra roja, los argentinos rubios hijos de colonos y la elaboración de yerba son referencia obligada del lugar"

${ }^{25}$ Folleto INYM 2018, "Origenes de la Yerba Mate"

26 "Hicieron que su consume se difundiera en forma extraordinaria."

27 "Los responsables de que la yerba fuera conocida en el mundo civilizado."
} 
Although the INYM and other popular discourse reinforces the idea that the Guaraní are people of the distant past, the Mbya Guaraní continue to live today and are still subjected to great exploitation and dispossession.

According to Schvorer (2011), in the 1960s and 1970s, as the agrarian frontiers expanded onto the Northeastern parts of the province, the Mbya Guaraní became a problem for the colonos and businessmen who would find that these indigenous communities were "occupying" their private property $(2011,17)$. Figures from the Mapa Guaraní Continental show that 54,825 Mbya Guaraní people live in Argentina as of 2015-2016. Of those, it is estimated that over 10,000 live in Misiones (Buliubasich, Casimiro Cordoba, and Flores 2016). Since the 1980s, rising indigenous movements across Latin America made advances for political rights and recognition (Schvorer 2011). The Constitutional Reform of 1994 recognized indigenous people and replaced a previous clause calling for "peace with the Indians and conversion to Catholicism" (Buliubasich, Casimiro Cordoba, and Flores 2016). A more recent reform is the Ley 26.160 de "Emergenia Territorial Indigena" which calls for the immediate suspension of all dispossession of indigenous communities. The Mapa Continental reports that in Misiones there is "a considerable part of the population that is not indigenous and that discriminates, exploits, and is ignorant of the rights of the Guaraníes." Further, although the aforementioned advances were made at the national level, the Misiones constitution has not incorporated indigenous rights and protections.

With Titrayju, MAM and the Cooperative Río Paraná have been able to circumvent some of the exploitative processes taken place in the yerba mate sector. Their involvement and success with the ferias francas and with the creation of INYM helped to create alternative economic solidarity networks and to regulate the yerba mate sector. Their marketing draws attention to the 
lives and struggles of the colonos, but what about the long, on-going history of yerba mate and the Mbya Guaraní? As previous scholars have pointed out, the identities wrapped in the constructions of national foods have important social and political implications. Mbya Guaraní communities are fighting for their rights with many of them working as tareferos ${ }^{28}$ Furthermore, Guaraní groups in Misiones have been advocating for a referendum that would to put into effect Ley 4000 in the Misiones Constitution, acknowledging the rights of indigenous people in Misiones. The law that would come into effect through this referendum would legally recognize their ethnic and cultural preexistence, guaranteeing respect for their identity and the right to bilingual and intercultural education, to be taught preferably by indigenous teachers and assistants. Further, it would call for the legal status of community and organizations with rights to managing their natural resources, and the rights to use, maintain, develop, and manage their own health services. Finally, the law recognizes the possessions and community ownership of the lands that the Mbya Guaraní traditionally occupy and regulates the return of other lands as suitable and sufficient for human development. The law would also ensure the protection of cultural heritage and intellectual property. The state's recognition of Mbya Guaraní communities, heritage, and lands is crucial for the survival of these communities. Their exploitation in yerba mate fields and through whitened narratives of Argentine identity need to be recognized and remedied through legislation and resource re-allocation. The vital step after passing this law will be advocating for legal titles to land and for fairly assessing land disputes. As mentioned before, a spokeswoman for ENDEPA reported that of the 120 Mbya Guaraní communities in Misiones, only 27 have legal titles to land. ${ }^{29}$

\footnotetext{
${ }^{28}$ Local newspaper article on forced labor: https://www.infobaires24.com.ar/misiones-guaraniesobligados-trabajar-tareferos-12-horas-cien-pesos/

${ }^{29}$ Guaraníes pidieron al Gobernador que convoque a un referendum. 2018. Retrieved on May 20, 2019 from: http://www.primeraedicion.com.ar/nota/100054136/guaranies-pidieron-algobernador-que-convoque-a-un-referendum/
} 


\section{CHAPTER III: SUPER YERBA AND AMERICAN SAVIORS}

Yerba mate's recent introduction into the American market provides an important case for understanding how certain foods are transformed to fit the well-worn grooves of prominent health food marketing and, in turn, how this process informs ideas of identity and nation building. The food movement has emerged in the last decade aiming to problematize the hegemonic global food system by positing that Western consumers can care for their individual health and the health of communities worldwide by choosing to purchase the "right" food products. As such, its adherents tend to be upper middle-class white Americans with the disposable income that yields this choice (Alkon and Agyeman 2011, 2). Yerba mate, like chai tea or rooibos, has permeated the American market under the emergent category of a health superfood. Loyer (2016) analyzes the concept of "superfoods" and points to their construction in marketing and popular discourse as a way to satiate many of the rising moral concerns about how processed foods lack nutritional content, contribute to environmental degradation, and exploit labor. In this way, superfoods merge contemporary discourses on the relationship between food, health, and values (Loyer 2016, 1).

In this chapter, I analyze the Guayakí Yerba Mate Company through the framework laid out by Loyer (2016) to unearth the symbolic representation of yerba mate in its marketing strategies and to better understand how it functions within current socio-economic power structures.

As a company that caters to millennial consumers within the alternative food movement, Guayakí addresses many of the concerns over nutritional content, environmental degradation, and unfair labor practices. Guayakí has been praised for its unique business model of "Market- 
Driven Restoration," now trademarked as "Market-Driven Regeneration," which employs a shade growing technique instead of the common monoculture plantations. Smith (2014) describes the company as the most successful in employing value-added processes taking place in the United States. These value-added processes include packaging, labeling, and creating blends that appeal to "North American tastes" (Smith 2014, 76). It is my hope that the discursive analysis presented here will further expand on the historical and economic processes that make up these "North American tastes."

Guayakí's relations with the indigenous Aché in Paraguay are central to its marketing and business model. Guayakí's product labeling created a new yerba mate narrative that constructed yerba mate as an indigenous product rather than an Argentine national symbol. Indigenous labor is central to its business model and, as I will show, its marketing has changed in ways that still strongly align with superfood marketing and that reconstruct and reestablish problematic American colonial structures with the Global South and between the American nation-state and the indigenous Other.

\section{Guayakí Company Profile}

Alex Pryor and David Karr founded Guayakí in 1996. Pryor, a Buenos Aires native studying food science, and Karr, a Californian studying business, became friends while at $\mathrm{Cal}$ Poly University in San Luis Obispo, California (Ceaser 2002). In 1995, Pryor visited Francisco Rivas' estancia in Alto Paraná, Paraguay, which held "undisturbed rainforest" with the potential of growing and harvesting yerba mate with labor provided by nearby indigenous communities (Ceaser 2002, 5). As Ceaser (2002) reports, Pryor saw an opportunity to sell this yerba mate in California because he saw that consumers wanted an alternative to coffee or tea $(2002,5)$. Pryor 
took 400 pounds of yerba mate to San Luis Obispo and started informing residents about it, "It took a lot of store demos and education materials to inform Americans, most of whom had never heard of yerba mate" (Ceaser 2002, 5). Aside from being simply an alternative to coffee, the yerba mate from Rivas' estancia obtained organic certification in 1996 and comes from a shade growing system rather than the monoculture plantation method that has contributed to further deforestation in the region. In this shade growing system, yerba mate plants are grown and harvested under the rainforest canopy.

Since its founding in the mid-1990s, Guayakí has expanded relations to other producers in the area. Today, the company sources its yerba mate leaves from Paraguay, Brazil, and Argentina. Guayakí works with producers to obtain organic and fair-trade certifications and holds workshops with field workers to teach organic harvesting methods while also requiring insurance and benefits for all workers (Ballvé 2007, 10-13). The company focuses on working with farms that are near protected areas such as national parks and wildlife preserves to create buffer zones and wildlife corridors in high priority areas for conservation (Ballvé 2007, 10-13). Although the company works with an array of small farmers, their name, and marketing highlights their relationship with the Aché, also known as the Guayakí, indigenous people. The company uses their name, "Guayakí," and has trained the Aché community of 40 families to grow and harvest yerba mate on their lands, located on the end of the Mbara-cayú Biosphere Preserve (Ballvé 2007, 10-13). According to Boyd et al (2009) in 2008 only 10 percent of Guayakí's the yerba mate came from families living in the Itabo Rainforest Preserve while 90 percent came from reforestation projects in Argentina and Brazil which included partnering with small family farms and cooperatives $(2009,69)$. 
Guayakí manages their relations with farmers and indigenous groups in the Atlantic Forest region through its main office for all South American operations in Buenos Aires (Smith 2014, 70). The company imports the yerba mate leaves to the United States, specifically California, where they have established their packaging and other value-adding processes. The company headquarters are in Sebastopol, California. As of 2008, Guayakí held 60 percent of the \$15 million U.S. market (Boyd et al 2009, 70). Since consumers in the United States are not familiar with yerba mate, and the traditional consumption through a gourd has not yet translated, Guayakí's value adding processes in the United States include transforming yerba mate into forms that abide by American food consumption patterns. As a result, Guayakí products include mate tea bags flavored with chocolate, mint, chai and others, as well as mate latte concentrates, bottled iced mate, canned mate, mate energy shots, and loose-leaf bags. The best-selling products are the 25-count traditional tea bags and the eight-ounce loose leaf mate bag (Boyd et al 2009, 70). Guayakí also sells gourds and bombillas and has been working on exposing American consumers to the traditional consumption method through a few different avenues which I will describe later on in this chapter. Overall, bottled drinks account for 45 percent of sales, dry products account for 50 percent, and the resting 5 percent include accessories (Boyd et al 2009, $70)$.

Guayakí has been growing steadily since its start in the early 1990s. Their products are not just sold in California but are distributed throughout the U.S. and parts of Canada through large national distributors and through wholesalers and partnerships (Boyd et al 2009, 73). Guayakí has partnerships with Tully's Coffee Corporation, Steaz Organic Energy, and Sambazon Amazon Drinks $(2009,73)$. In 2008, Guayakí was in near break-even status at an annual revenue of 7.3 million (Boyd et al 2009, 64). In Guayakí's recent “Global Impact Report," the 
company states that their 2017 revenue amounted over $\$ 60$ million, a 24 percent increase from 2016. Boyd et al (2009) observe that "Guayakí can talk about many aspects of its products they are organic, fair trade, environmentally beneficial, and a healthy stimulant" $(2009,74)$. As many other superfoods, the ways in which this company has structured itself and its products marks a change in the way that food is marketed and conceived. The "many aspects" show important insights on the ways that companies perceive consumer demands and communicate ideas about personal health, environmentalism, and identity.

\section{The New Nutrient Powerhouse}

Brewed from the naturally caffeinated and nourishing leaves of the species of holly native to the South American Atlantic rainforest (Ilex paraguariensis), it contains 24 vitamins and minerals, 15 amino acids, and abundant polyphenols. Remarkably, the Pasteur Institute and the Paris Scientific Society concluded in 1964 that "it is difficult to find a plant in any area of the world equal to mate in nutritional value" and that yerba mate contains "practically all of the vitamins necessary to sustain life. ${ }^{30}$

Yerba mate's many nutritional benefits are an important part of Guayakí marketing consistently mentioned in product labeling, website content, social media posts, and other promotional materials. Loyer (2016) positions superfoods as products of and backlash to the dominant discourse of functional nutritionism. Under the paradigm of nutritional science starting in the mid-nineteenth century, food began to be understood through a reductionist approach that focused on nutrient composition and its effect on bodily health and function (Loyer 2016, 16). Since the mid-1990s popular nutrition discourse has shifted from focusing on prescribing the avoidance of certain "bad" foods to emphasizing the consumption of "good" foods that improve healthfulness $(2016,17)$. Further, Loyer underscores Scrinis' (2013) claim that rather than just

${ }^{30}$ Guayakí company website: https://guayaki.com/yerba-mate/ 
improving health, in the "era of functional nutritionism... you enhance your health and target particular bodily function and processes" $(2013,4)$. Through certain nutritional components in foods, individuals can enhance specific bodily functions and processes which leads to a conceptualization of both foods and bodies as mechanical and functional. Highly processed, artificially flavored foods fortified with vitamins epitomize functional nutritionism (Loyer 2016, 18).

The Guayakí product labeling designed to attract the American consumer illustrated in Figure 10 uses the functional nutritionism discourse to communicate the healthfulness of the product. The labeling introduces a list of health benefits, claiming such things as "supports focus \& clarity," "contains antioxidants" and "aids elimination" (Figure 10). It also suggests that yerba mate has been used to "traditionally support weight loss programs that include a balanced diet and exercise" (Figure 10). This language aligns with the view that foods are composed of certain micro and macro nutrients that support specific bodily functions. The antioxidants and other nutrients in yerba mate help bodies become more focused and efficient by promoting elimination and weight loss. 

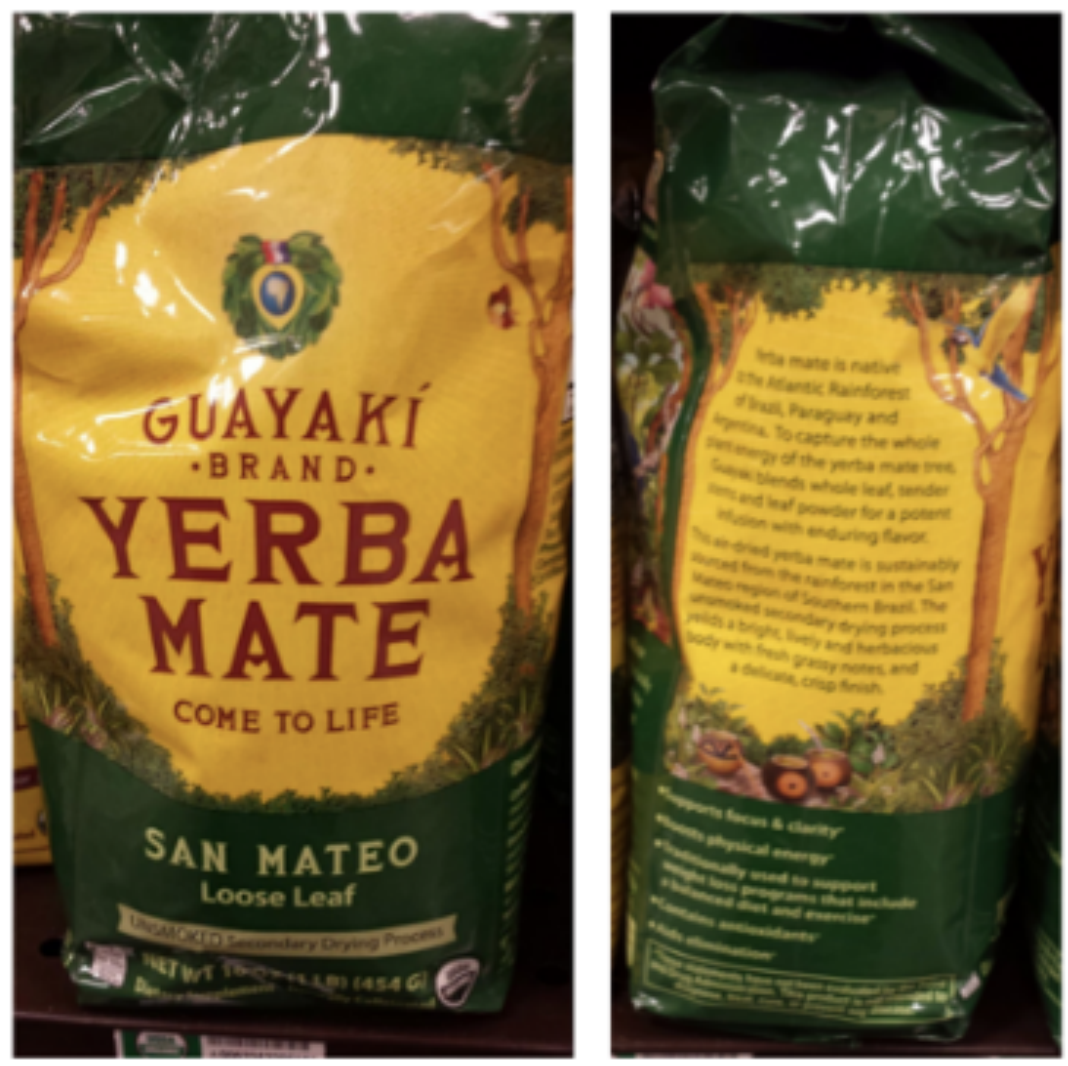

Figure 10. Guayakí Product Label Front and Side. Photo Taken by author.

A simple Google search for "yerba mate" yields the Guayakí company website and its social media presence as its first result. It follows with a list of suggested questions depicted in Figure 11, mainly concerned with the healthfulness and effects of yerba mate consumption, as well as its potential as a substitute for coffee.

\begin{tabular}{l} 
People also ask \\
Why is yerba mate bad for you? \\
What are the benefits of Yerba Mate? \\
\hline Is yerba mate healthier than coffee? \\
\hline What are the side effects of yerba mate? \\
\hline
\end{tabular}

Figure 11. Google Search for Yerba Mate. Screenshot taken by author on March 20, 2019. 
These questions have become important in popular discourse because contradicting claims and skepticism of the food industry amidst rising health issues like diabetes have led consumers to feel anxious and confused about what to eat. With increasing distrust and anxiety towards functional nutritionism, superfoods have emerged as a solution for consumers that have internalized the concept of functional nutritionism but are highly skeptical of the food industry's highly processed and technologically engineered foods (Loyer 2016). Here, I argue that yerba mate has been transformed as a superfood through the same functional nutritionism rhetoric, accompanied by labels that also present it as "naturally" nutrient rich and not tainted by additives and technological processing.

Consequently, consumers are responsible for making informed choices about their food based on the micro and macro nutrients in foods if they wish to be healthy and optimize their bodily function. A plethora of sources pledge to inform consumers on the right types of foods and ideal diet for increasing productivity, growing strong bones, reducing wrinkles and many more desirable features and functions. Corporations often lead the charge in some of these studies to prove that the nutritional components packed into their food products will help consumer health outcomes. These discussions are also propagated through popular discourse in the media and other sources of information.

Scrolling past the Guayakí marketing yields articles that further discuss the many health benefits of yerba mate within the framework of functional nutritionism. A Healthline.com article is titled, "The 8 Health Benefits of Yerba Mate (Backed by Science)" and informs consumers on the nutritional benefits of yerba mate including, "improving mental focus," "enhancing physical performance," and "boosting the immune system" among other benefits. Another article from BeBrainFit.org also provides a list of "10 Benefits of Yerba Mate Tea (Better Than Coffee)." 
The functional nutritionism discourse as used by Guayakí in their marketing and by these articles suggests that discourse about yerba mate is framed and targeted to health-conscious and anxious consumers looking for "healthy" alternatives in their current distrust of mainstream American foods. More specifically yerba mate is situated as a healthy stimulant that can substitute drinks such as coffee, tea, and other energy-boosting drinks.

\section{Your Morning Fix: Empire and Capital Extraction}

The rhetoric in many U.S. sources about yerba mate often present it as an alternative to coffee. For example, Guayakí explains yerba mate as follows:

Yerba mate has the strength of coffee, the health benefits of tea, and the euphoria of chocolate, all in one beverage. ${ }^{31}$

The connection to coffee in the Guayakí marketing is specifically for the purposes of communicating to consumers the stimulating caffeinated properties of the herb. Although this may seem like an obvious point, it is important to highlight that there are other properties and comparisons between yerba mate and coffee, especially in fair trade networks, that could be made apparent by Guayakí's marketing. For example, many coffee and tea ventures in the alternative food movement currently make use of the same shade-growing system espoused by Guayakí. Before delving into a discussion about the environmentalist dimensions of the marketing and shade-growing aspects, I turn to further discussing the idea of yerba mate as a coffee alternative for Americans and why Guayakí focuses on this particular connection.

In yet another top Google hit under yerba mate, on January 15, 2019 a potential consumer posts a question on the Mayo Clinic website section, "Expert Answers:"

${ }^{31}$ Quote retrieved from: https://Guayakí.com/yerba-mate/ 
A friend suggests that I try yerba mate tea to boost my energy. What is yerba mate? ${ }^{32}$ The Mayo Clinic doctor responds with a general description of yerba mate as a beverage common in South America which contains caffeine and is therefore a stimulant. The response also mentions that studies have shown an increased risk of certain cancers among persons who consume large amounts, and therefore prescribes consumption in moderation. Similarly, the aforementioned Healthline article ends with a "Safety and Side Effects" section that includes the same remarks about a study on increased risk of cancer, as well as a warning about "caffeine related side effects" and "medication interactions." These articles at the top of internet search results on yerba mate show the medicalization of the drink (Zwier 2009, 109-113). As framed by Loyer (2016), superfoods, like yerba mate, straddle social categorizations of food and medicine and are "good to think" because "they challenge taken for-granted social categories and open up new possibilities for critical reorganization of the social world" $(2016,11)$.

As an alternative to coffee, the main medicinal purpose of yerba mate is to address fatigue, lack of energy, lack of focus and through this particular property it is presented, like coffee, as a drug food. Coffee holds a sordid history and has important social implications and economic functions in American society. Similar to yerba mate in South America, coffee drinking and coffee houses promote sociability and egalitarian conversation (Ellis 2008, Elyachar 2010, Manning 2012). Coffee drinking is extremely ritualized and a staple of most workplaces and households in the Western world. Further just as yerba mate has been used for nation-building in Argentina, coffee, like tea, chocolate, and sugar, have been famously analyzed as crops of empire (Mintz 1986, Pendergrast 2010). In 1650, the opening of the first coffee house

\footnotetext{
32 Retrieved from: https://www.mayoclinic.org/healthy-lifestyle/nutrition-and-healthyeating/expert-answers/yerba-mate/faq-20058343
} 
in England marked the sobering up of the Western empire with a switch from numbing drug substances like opiods to those that promote energy and alertness (Pendergrast 2010). This time period was also marked by colonial expansion where the extraction of these crops aided the subjugation of native peoples and the development of colonial economies (Jankowiak and Bradburd 2003). The extraction of labor in Western society is aided through the consumption of energy-boosting substances to discipline labor. In the United States, coffee breaks became popular to energize factory workers keeping them away from alcohol and became pervasive in office settings to increase productivity (Jankowiak and Bradburd 2003, Mintz 1986). As such, coffee continues to be used today by the American worker primarily to increase their productivity and aid capital extraction.

Folch (2010) argues that although yerba mate has a similar history in South America, it was mostly contained to its region of origin as opposed to coffee and tea because the Spanish empire's structure differed from the British, Dutch, French, and Portuguese in that "yerba production was primarily oriented toward royal tribute rather than to the streamlining goals of a market economy" $(2010,19)$. Folch further comments that yerba mate has not been successfully grown outside of the Atlantic Forest region and therefore was less accessible to naval transportation. By the time that coffee and tea were made popular in Europe and the United States, yerba mate had some stiff competition. Interestingly, Folch argues that "marketers did not not sufficiently distinguish it from coffee or tea but instead positioned it as a mere substitute" $(2010,20)$. As mentioned, the anxiety over what to eat in the alternative food movement has driven consumers to look for food alternatives. This is why today marketing yerba mate as a substitute to coffee may be more amenable than before. However, to Folch's point, Guayakí makes parallels to coffee but does not market yerba mate as merely a substitute. The alternative 
food movement has created a space for Guayakí to market yerba mate as much more than just an energizing drink.

\section{The Yerba Mate Drinker and Activist}

Loyer (2016) explains that what makes superfoods "super" is that their health benefits are provided "naturally." The importance of this connection with the "natural" stems from consumers' anxieties about production techniques and serves to show the consumer that the product has not been corrupted by technology and that its production is in harmony with nature. Consequently, superfoods incorporate a second discourse of food and health: critical consumption (Loyer 2016). "Organic," "Fair-Trade," and other such certifications aim to inform consumers about the "natural" and ethical production practices employed in harvesting superfoods. This narrative is desirable to the consumer who is disenchanted and skeptical of the

food industry. As shown in Figure 10, Guayakí's yerba mate label includes certifications such as "USDA Certified Organic" and "Fair for Life Certified." This signals to consumers that the product has not been genetically modified and that the company has taken some measures to improve the environmental and human conditions of its supply chain. This critical consumption discourse makes up an important part of the marketing and structure of companies selling superfoods. In the Guayakí website, the company states the following vision:

Our vision holds that yerba mate culture will power our Market Driven Regeneration ${ }^{\mathrm{TM}}$ business model to regenerate ecosystems and create vibrant communities. ${ }^{33}$

Further, we find similar language on the product labeling in Figure 10, where Guayakí highlights their sustainable methods of production:

${ }^{33}$ Quote from: https://Guayakí.com/vision/ 
Guayakí's mission is to steward and restore 200,000 acres of South American Atlantic Rainforest and create over 1,000 living wage jobs by 2020 by leveraging our MarketDriven Restoration.

Marshall (2011) examines Guayakí, among other companies, to gain a deeper understanding of international for-profit social enterprises. He concludes that these social enterprises are "(1) committed to a global issue and (2) maintain a fundamental belief in the market as a transformational mechanism to address the social issue" $(2011,196)$. The product's success depends heavily on the consumer who must be persuaded by the company's mission and their messaging to purchase their product over another. Therefore, purchasing yerba mate products from Guayakí is marketed as something beyond purchasing an energizing drink, it is marketed as a political action. In its Global Impact Report Guayakí delineates this as follows:

We are building a culture around conscious engagement and purpose for those that believe we have the collective will and skills to create a world where all of us can thrive.

One of the problems with market-driven solutions pitched as social movements is that they are exclusive. Boyd et al (2009)'s study notes that Guayakí makes a "high quality, premium product" which means that like many other health food products, its price point is targeted at those with disposable income $(2009,64)$. Furthermore, Boyd et al (2009) goes on to state that "Guayakí internalizes the additional costs of fair trade and organic certification into its business model and allows customers who value these ideals to make a statement with their purchasing power" $(2009,74)$. A person can only be part of Guayakí's “collective will” to "regenerate ecosystems and create vibrant communities" if they have the purchasing power to consume Guayakí products.

As other scholars have pointed out, membership in the food movement happens through purchases (Alkon and Agyeman 2011, 1-20). Furthermore, as Fridell (2007) summarizes 
previous research, "internationally, fair-trade depends on existing consumption patterns which are characterized by 'overconsumption' in the North" $(2007,80)$. Wealthy Northern consumers who have disposable income buy into consuming their way out of complex environmental and social justice problems. Along with reifying existing over consumption in the North, CurridHalkett (2017) argues that material goods as symbols of high class have diminished due to their accessibility, instead "the aspirational class has altered its consumer habits away from overt materialism to more subtle expenditures that reveal status and knowledge." Along with breastfeeding and yoga classes, buying organic foods is a new class marker of the American elite. Veblen's “conspicuous consumption" of luxury goods as markers of status is replaced by much more subtle symbols where status is signified through knowledge. Moreover, Freedman and Jurafsky (2011) analyze potato chip marketing and find that "more expensive chips thus come wrapped in more complex language, presumably designed to draw a potential buyer into believing that the product is somehow consonant with his or her educational capital" $(2011,49)$. As we can see in Figure 10, Guayakí labeling is not only wrapped in text but it also includes more complex language, such as "rejuvenative," "steward," and "leverage."

Aside from being a class marker in the United States, these market-driven solutions are also markers of the international status of Northern consumers. As Fridell (2007) observes, "as is the case with conventional consumerism, fair trade consumerism accepts that the needs of poor Southern producers are ultimately subservient to the demands of Northern consumers" (2007, 87).

Freedman and Jurafsky (2011) also point out that authenticity in potato chip advertising for the upper class is communicated through "an obsession about the quality and origins of the ingredients and their cooking process" $(2011,51)$. Although I have already discussed the 
"natural" rhetoric in Guayakí, Freedman and Jurafsky take me to discuss another important facet of the critical consumption discourse. The alternative food movement aims to defetishize commodities by connecting consumers to sites of production. It is through this process that Guayakí aims to distinguish itself from other brands.

Boyd et al. (2009) points out that Guayakí's main competitor is Eco Teas, an Oregonbased company that holds 30 percent of the yerba mate market. Eco Teas sells the same onepound loose leaf yerba mate at half the price of Guayakí's loose leaf bag. Boyd et al.'s (2009) interviews with Guayakí reveal that they see their product as being of higher quality because of their shade growing technique $(2009,75)$. In another interview, Karr, Guayakí's co-founder, explains to Marshall that their "goal was to create consumer demand for healthy rainforest products, providing native people with alternative land use practices" $(2011,192)$. In this way, Guayakí highlights the origins and process of production for its Northern consumers. Guayakí employs indigenous people to cultivate yerba mate leaves from the forest which appeals to the American consumer who is persuaded by the idea of connecting with nature by exoticizing indigenous people while also saving them and their environment. However, yerba mate harvesting directly from the dense and swampy Atlantic Forest is incredibly difficult. Consequently, in the shade growing system most of the rainforest still has to be chopped down in order to plant the yerba mate bushes; only the tallest canopy trees remain (Ceaser 2002, 5). As Ceaser explains, this preserves the habitat for birds but removes rodents, reptiles, amphibians, and insects living on the forest floor (Ceaser 2002, 5).

Guayakí puts a heavy emphasis on its shade growing system and even trademarked the phrase "Market Driven Regeneration" to refer to their business model. In fact, in their 10-page, approximately 2000-word Global Impact Report, the word "regenerate" is used 33 times. In their 
product labeling and their company name, they heavily emphasize their connection with the Aché indigenous people. In many ways the shade growing system employed by Guayakí is similar to the encomienda system where the Guaraní harvested yerba mate directly from the Atlantic Forest for tribute to Europe.

It is in this way that critical consumption discourse intersects and supports primitivism in ways that are particularly important for our understanding of the nation-state. The shade-growing method and yerba mate's "natural" nutritional benefits are further authenticated through a framework that Loyer (2016) calls the folk or indigenous wisdom knowledge framework. The marketing exhibits a discourse of primitivism to authenticate "natural" foods with producers who are generations of people perceived to be untouched and in opposition to the post-industrial present. Primitivism or the concept of the "noble savage" in anti-modernist movements of the 1960s portrayed indigenous peoples as nonviolent, cooperative, in harmony with nature, and victims of Western aggression (Di Leonardo 1998, 32). Therefore, "our role as modern Westerners, then, is to let primitives teach us their "tribal wisdom;" yet in these modern capitalist societies this "teaching" happens through a commodification of "tribal wisdom" which leads to "salvation through consuming the primitive" (Di Leonardo 1998, 34).

In opposition to the post-industrial present, the Guayakí labeling includes images that resemble the rainforest with a butterfly and a toucan (Figure 12). Although the labeling does not show any indigenous people, it features a narrative that aligns with the nutritional primitivism discourse seen in other superfoods. The text assures the consumer that the Aché indigenous people have consumed and produced yerba mate "for centuries," as shown in Figure 12. The labeling promises a connection to nature with its tag line, "come to life" (Figure 10). The consumer is also left to assume that yerba mate and its Aché producers live in some faraway 
exotic rainforest or jungle. The text in the bottom right corner of Figure 12 further connects this sense of nature to an exoticized indigenous Other when it claims that:

Guayakí Yerba Mate is made from the naturally caffeinated and nourishing leaves of the celebrated South American rainforest holly tree Ilex paraguariensis. For centuries, South America's Aché Guayakí tribes have sipped yerba mate daily for its powerful and rejuvenative effects.

The discourse aims to authenticate yerba mate through ancient, indigenous wisdom and the vague rainforest images along with this text serve to reinforce the idea that yerba mate comes from a timeless place, untouched by industrialization and modernity. Furthermore, as Loyer (2016) argues with the case of maca root, this exoticism portrays hyperbolic claims about ancient wisdom being passed down from generation to generation $(2015,8)$. Although the Aché may consume yerba mate today, scholars have argued that this was not always the case. In fact, yerba mate history is closely tied to the indigenous Guaraní, which are a different indigenous group. The Aché "distinguish themselves from other indigenous Paraguayan groups on the basis of linguistic and behavioral patterns and material culture" and they "refer to themselves as "Aché"” (Hurtado and Hill 1996, 41). In some early ethnohistoric accounts, the Aché are distinguished from their Guaraní neighbors because "they don't recognize chiefs and they don't make use of the Paraguayan yerba, that is so abundant in the area" (Hurtado and Hill 1996, 46). Other Guaraní native populations and Paraguayans use the word "Guayakí" to refer to the Aché indigenous group, however the Aché people themselves find this term offensive since it has derogatory connotations (Hurtado and Hill 1996, 41). 


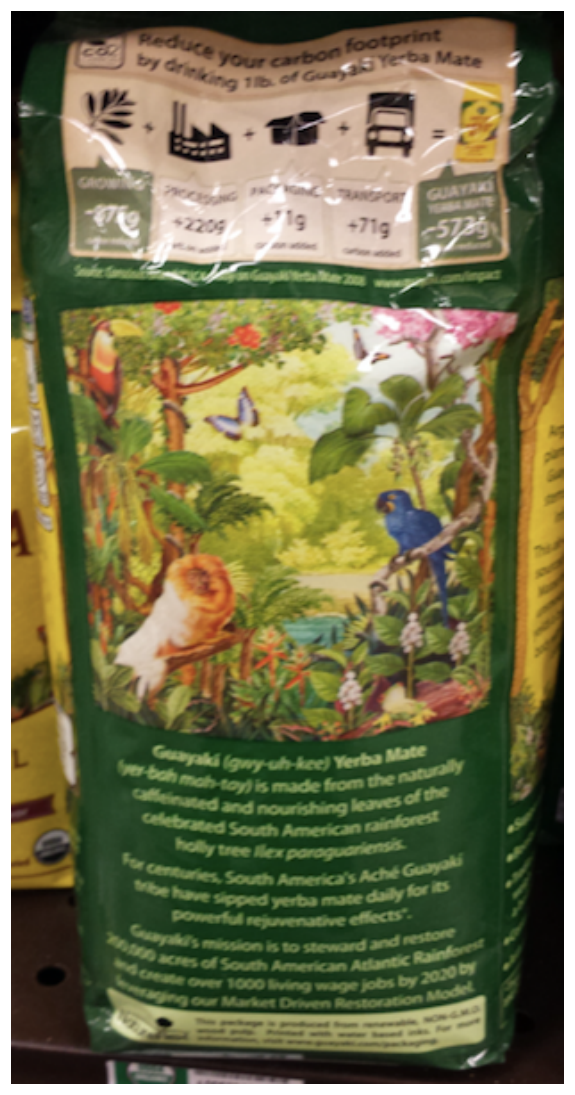

Figure 12. Guayakí Product Label Back. Photo taken by author.

The Guayakí marketing is attractive to the U.S. consumer whose search for authenticity in this product does not extend past a shallow portrayal of indigeneity. Historically, the commodification of indigeneity has been part of a nation building strategy where "American" culture and identity has been defined in opposition to an indigenous Other. This conception of indigeneity stems from the early nation making strategies of the 1840 s where leaders justified continental expansion into indigenous lands as a divinely ordained mission to extend the "boundaries of freedom" to others by imparting their idealism and belief in democratic institutions to those who were capable of self-government (Mitchell 2014). Manifest destiny revitalized a sense of "mission" or national destiny for Americans and at the same time envisioned those "unfree" regions as wild, uninhabited, or inhabited by people incapable of selfgovernment, such as Native American people and those of non-European origin. In this way, 
“"the idea of America' integrated a set of apparently untroubled assumptions about nature, progress, and the past... the constant lure of a fresh start" (Mitchell 2014, 4). Yet, it also created an incomplete American consciousness as a result of "wanting to have their cake and eat it too," of wanting both civilized order and savage freedom (Deloria 1998, 3).

In this conflicting American national imagining, indigeneity is seen both as savagery that is in opposition to a civilized national Self and must be despised and conquered, as well as a desired wildness and freedom in harmony and connection to the North American land that must be emulated (Deloria 1998, 3). Americans have appropriated indigeneity and "played Indian" to express their own struggles and to create dominant narratives about the American nation. As Deloria explains, "from the colonial period to the present, the Indian has skulked in and out of the most important stories various Americans have told about themselves" (Deloria 1998, 5). Many industries, apart from the food industry, have taken advantage of U.S. mixed disdain and desire for indigeneity by unapologetically commodifying it. Schwarz (2005) demonstrates how commodifying Native American material and non-material culture in the mass-market toy industry where Native American barbies are sold to middle class white children is a continuing colonial project where European Americans can consume indigeneity and "play Indian" $(2005,298)$. This is projected in the case of Guayakí Yerba Mate where Guayakí offers a connection to tribal wisdom through the consumption of the alleged Aché tradition of yerba mate drinking. Incorporating yerba mate into the American diet may to some food scholars seem like another ethnic food melding into the American melting pot. However, I argue that yerba mate's marketing as a superfood and by extension as an indigenous product is an act of banal nationalism that underscores the problematic standing of indigeneity in the U.S. 
Smith concludes that Guayakí is one of the few companies that "is concerned with preserving traditional livelihoods and ecosystems, instead of following the road of pure resource extraction and producer marginalization" (Smith 2014, 86). Yet their success with consumers in the United States has been predicated on how the company leverages problematic nationalistic U.S. desires about indigeneity and which continue to marginalize them.

Amidst a growing market and increasing global access to brands like Taragüi, and even Titrayju, Guayakí communicates its authenticity to Northern consumers in line with other fairtrade superfoods. However, such a different reimagining of yerba mate has caught the attention of people like myself who are familiar with yerba mate in South America. It has also become apparent to Guayakí consumers who become avid yerba mate drinkers and start researching it themselves. One important online source for these cultural translations, is the "Yerba Mate Blog." Figure 13 illustrates this conflicting sentiment in the "About" section of the blog. The Brazilian blogger identifies the functional nutritionism rhetoric around yerba mate and decides to start this blog to inform "foreigners" about mate culture. 


\section{Welcome to the Yerba Mate Blog!}

You may think I have created this blog, because I am absolutely in love with Yerba Mate. Well, that's true! I drink Yerba mate every day; not just because it is healthy, but rather because drinking mate is a ritual that is deeply rooted in my native country of Brazil. Most importantly, I created the Yerba Mate Blog, because I wanted to share with you some information about the origin of mate as well as some of the myths and legends that are so much present in mate culture.

You see, while surfing the internet, it has come to my attention that more and more foreigners are becoming acquainted with mate and/or are looking to it as a healthy and affordable

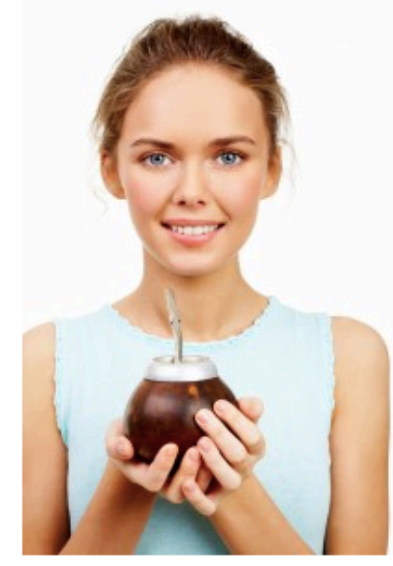
alternative to coffee. Although it is true that drinking Yerba Mate is indeed a healthy habit, there is much more to it than just the health benefits. I couldn't help noticing that most of the Yerba Mate discussions out there don't really go beyond the advantages (or disadvantages) of drinking mate. Though they are all bloated with smart talk and scientific explanations, they don't even begin to scratch the surface of the meaning of drinking Yerba Mate.

Figure 13. Yerba Mate Blog Description. Retrieved September 19, 2018 from http://www.yerbamateblog.com/about/

In one of many posts that attempt to translate the social and cultural significance of yerba mate to Northern consumers, the blogger decides to interview Guayakí co-founder and Vice President of Marketing, David Karr. The blogger states that they have not tried any Guayakí products because they are not widely available in their area and because of the high cost. The blogger also says that after going through their website and videos online and got a "full picture of their work in South America" but "still knew very little about their operations in the United States." Their focus for the interview was to get an understanding of "the type of people who consume their products and just how did they manage to bring such a traditional beverage to such an 'untraditional' market."

As illustrated in Figure 14, the blogger reveals that they often get messages from American consumers questioning the authenticity of Guayakí. In response, Karr emphasizes their 
shade growing method as their ultimate proof of authenticity, suggesting that Guayakí is even more authentic than local brands because they "solely source (compared to other brands) mate from its native environment (shade of the rainforest)" and because their producers are "exclusively small farmers and indigenous tribes." Guayakí like other brands aims to defetishize their product by speaking to their "natural" processing and their connection to producers.

\begin{abstract}
Guayakí is a US brand and I often get emails from American yerba mate drinkers, who have only recently been introduced to yerba mate. Most of them are consuming your brand, but write me asking for advice on which brand to try next. A typical email will start like:

"My name is ... I have been drinking yerba mate for a few months now. I started with Guayakí, because it everywhere here in my area, but now I am ready to try some other brand....

They seem interested to "move on" as they question the "authenticity" of the Guayaki taste when compared to traditional South American brands like Rosamonte, Cruz de Malta, Barao, etc.. Is there really a difference? What would you say to them?

- I don't hear that a lot, (maybe they do in our customer care department). I would answer that they should try any brand for reference and that we are the most authentic mate brand because we solely source (compared to all other brands) mate from its native environment (shade of the rainforest) unlike other commercial brands who have cultivated mate in the sun for ease of harvest and higher yields. moreover, we work exclusively with small farmers and indigenous tribes to procure fairly traded, certified organic mate, again making it a more authentic mate experience - closer to its roots (before it was commercially produced).
\end{abstract}

Figure 14. Guayakí: Everything You Ever Wanted to Know. Yerba Mate Blog. Retrieved September 19, 2018 from http://www.yerbamateblog.com/guayaki-everything-you-ever-wanted-

\title{
to-know/
}

When Karr says that this processing method is "closer to its roots (before it was commercially produced)," he is speaking very romantically about a complicated history of oppression and colonial expansion. Although the branding has emphasized this indigenous connection from its founding, it has recently done some rebranding that does not emphasize the Aché indigenous group or peasant communities they partner with. Instead, their new website posits "yerba mate culture" as synonymous to the Guayakí brand with little mention of Argentina, Brazil, or 
Paraguay other than to give a general context of where the product is produced. Although there is still no mention of yerba mate drinking through a gourd in most of their products, Guayakí now offers a $5 \mathrm{lb}$ bag of yerba mate that does include a description that reads,

Traditional Mate Gourd: Yerba mate is traditionally prepared in a gourd and shared among a circle of friends. Welcome the moments of community born of your own mate circle. ${ }^{34}$

The product labeling itself has also been simplified, keeping nature graphics, and removed mention of the Aché (Figure 15). The new branding continues to emphasize the nutritional benefits of yerba mate through their website. The new branding focuses more on the Market Driven Regeneration ${ }^{\mathrm{TM}}$ model and its vision to "power our Market Driven Regeneration ${ }^{\mathrm{TM}}$ business model to regenerate ecosystems and create vibrant communities." ${ }^{\text {35 }}$ Instead of centering on the Aché, the new branding centers on a Guayakí community composed of "Amigos" and "Ambacebador." "Amigos" seem to be social media influencers that promote yerba mate drinking both on the Guayakí website and through their personal brand in other social media accounts. The Ambacebador is described as "someone who shares and serves yerba mate" and "will be actively involved in growing awareness of both yerba mate and the Guayaki brand across your university campus and the social networks that you're involved in." This new way of targeting young college age consumers is interestingly similar to the college students in Cordoba and it is interesting to ponder what cultural understandings Guayakí has deemed worthy to keep and what it ignores. As mentioned, a connection to any nationality is not shown. Perhaps because this would mean the making of yerba mate into an "ethnic food" rather than a staple replacement of coffee or other energy drink. In line with

\footnotetext{
${ }^{34}$ Retrieved from: https://guayaki.com/shop/fg-01-00021/

${ }^{35}$ Retrieved from: https://guayaki.com/vision/
} 
this, Guayakí does use any South American yerba mate terminology. They do not at any point use the word "mateada," instead they have chosen to say, "share the gourd." The only term Guayakí uses is the Spanish word "cebar" or "cebador" which refers to the person who pours the water into the gourd. However, even this term they have made their own by combining it with the word "ambassador."

The Amigos page presents sixteen profile photos and describes the individuals as a "creative community of folks" who follow varying types professions "from photographers to surfers to environmental activists." 36 They are further described as "talented" at their professions but also as participating in "give back to their communities and the planet." It is unclear initially what these people's roles are within the company. Each portrait links to a short biography with more pictures. In each person's individual profile, we learn a bit more about what "amigos" do with Guayakí and where they live. Most of them are based in the United States, with some in Canada and two Argentinian brothers. Aside from brand promotion some of them seem to be working to create recipes for different flavored drinks what the founder calls "blends for American tastes." In their profile pictures, only two of them are drinking Guayakí products. Most are facing the camera, wearing very casual clothing and smiling while posing outdoors in various natural environments. Overall, it seems to be that "amigos" are a group of young people visiting amazing natural places, in many different climates with adventurous lives in the outdoors. None of them sit in desks or cubicles and there are no skyscrapers or urban landscapes depicted. Although the Market Driven Regeneration ${ }^{\mathrm{TM}}$ model still rests on the power of the Northern consumers to take pity on the South American peasant and indigenous person, Guayakís new

${ }^{36}$ Retrieved from: https://guayaki.com/amigos/ 
social media marketing shifts the focus to the desires of young, Northern consumers based on some of the same antimodernist sentiments.

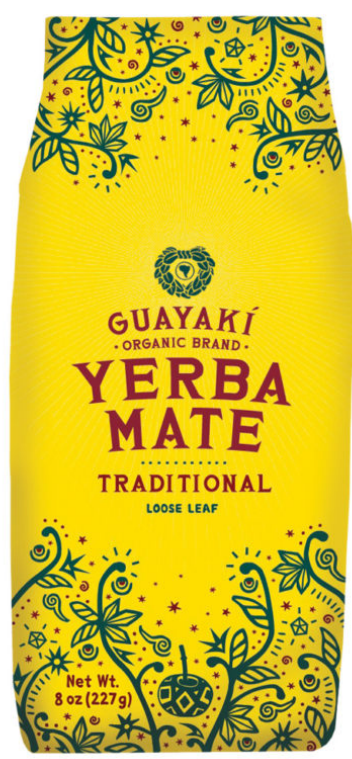

Figure 15. Guayakí New Label. Retrieved May 20 from https://guayaki.com/shop/category/loose-leaf-yerba-mate/ 


\section{DISCUSSION}

The marketing of these three different yerba mate brands highlight a few different social and political issues. In the cases presented in Argentina, yerba mate is an important commodity for the Argentine state not only because of its economic viability but also because of its role as a symbol of national identity. As I have described, the production of yerba mate united immigrants from varying nationalities under one common purpose. Evolving over time, the gaucho and his yerba mate drinking became indexical to Argentine national identity and an imagined, romanticized origin that obscures indigenous roots. New immigrants, not just in Misiones but throughout the country, adopted yerba mate to assimilate into Argentine culture. Technological advances and top-down processes and policies promoted the mass production and consumption of yerba mate. These processes have contributed to yerba mate's understanding as ubiquitous to Argentines. As studied by previous historians and anthropologists, Argentine national identity has exhibited a process of whitening that, I argue, is very present and signified in yerba mate. The land expropriations in current-day Misiones and Corrientes coupled with the promulgation of European immigration, has imagined the region as homogenously white, the land of "red dirt, blond Argentines, and yerba mate." This narrative persists in the stories that are told about yerba mate by producers, the INYM, and popular media even though Mbya Guaraní communities continue to exist in Misiones, are often exploited for yerba mate harvesting, and have been fighting for titles to land.

Adding insult to injury, when an American company find an opportunity in the health food movement and decides to highlight the Aché for yerba mate drinking and consumption, they ignore the Guaraní and further invisibilize them. As I have argued, this process transforms yerba mate into a superfood that heavily exoticizes indigenous people, a tactic that has long been 
economically viable in the United States. Although Guayakí and Titrayju may be helping in highlighting populations that have been and continue to be marginalized by the global economy, the business of yerba mate has a long history of oppression of the Guaraní people. As such, the narratives, symbols, and pieces of history and culture that these brands have decided to showcase continue to promote colonial processes that subjugate indigenous people.

These new models also put into question the capitalist relations between producers and consumers. They attempt to find alternative economic relations that aim to be more inclusive of peoples and the rural environment. The superfood phenomenon in the United States and the Guayakí case in particular calls on upper-class consumers to engage in critical consumption and to think about indigenous producers and forest habitats. These important parts of superfood advertising could potentially have a positive impact on communities if the stories shared on labels were more engaged with local histories and political struggles. As I have noted, however, Guayakí has recently moved away from a marketing strategy centered on the Aché and towards messaging that portrays mate as a "lifestyle drink" drawing on desires for nature and adventure of young, Northern consumers.

Titrayju, on the other hand, meets with Argentine consumers in local markets and solidarity networks. Their refusal to sell to supermarkets marks an important way in which they aim to defetishize the product. In this way, Titrayju also creates social relations and social spaces with consumers. As such, consumers themselves had a hand in defining what Titrayju meant to them: resistance. The piqueteros even appropriated it as a symbol of their struggle.

In the case of Guayakí, its global nature makes it more difficult for Northern consumers to truly engage in shared struggles, especially when indigenous histories are obscured. While Titrayju is concerned with food sovereignty, Guayakí makes a stronger case for environmental 
concerns with their "market-driven regeneration" model. Shade growing yerba mate seems to be a better alternative than high-yielding monocultures but what does it mean for local communities in South America when a transnational business creates a larger consumer base for yerba mate in the Global North? Guayaki is engaging the fundamental capitalist tenant of endless economic growth. Although shade growing techniques may be less environmentally harmful than monoculture plantations, they are still deeply embedded and serve to reproduce the power structures that oppress indigenous populations and continue to harm the environment in the pursuit of profit. Given current degradation of the Atlantic Forest region, it seems unlikely that further increasing consumer demand for forest products would reduce the ecological burden on the region. This is especially important considering that yerba mate is such a widespread and important cultural symbol to inhabitants of South America. It is important to consider that the neoliberal policies making it possible for companies like Guayakí to operate transnationally are also responsible for the success of large agribusiness; the primary driver in deforestation. Current economic policies favor transnational businesses like Guayakí and large corporations like Taragüi, Las Marias.

As Wahren and Guerreiro (2014) point out, the transformations in the agricultural world in the past decades have deterritorialized and excluded rural peoples, both campesinos and indigenas, for the purposes of agroindustry and agribusiness. Movements like MAM have created new political subjectivities that serve to dispute land grabs and ascertain food sovereignty. Wahren and Guerreiro (2014) also discuss that the construction of "any type of territorialization means, almost always, the destruction of another type of territoriality" (2014, 279). The different symbols of yerba mate in this study show some of these claims to territory and political identity, and how they often erase or undermine others. It is my hope here to draw 
attention in particular to the erasure of the Guaraní people and to visibilize, valorize, and lend support to their current struggle for land and political representation. 


\section{CONCLUSION}

This research describes the ways in which yerba mate came to be a national symbol in Argentina through the agricultural colonization of the northeastern region of the country. I've analyzed how yerba mate marketing is linked to the blanqueamiento or whitening of the Argentine national narrative in which the indigenous Guaraní are mostly excluded and invisibilized. Since the marketing continues to reinforce this whitened narrative, its everyday consumption reproduces the idea of Argentinians as "white" European settlers excluding indigenous groups from the national imaginary. This highlights a serious issue of disempowerment from social and political structures for the indigenous people in Argentina.

There are similar implications for indigenous groups in the United States, where yerba mate is reimagined as an indigenous product with little regard to the actual cultural traditions of the indigenous people exoticized on Guayakí's product labeling. While Argentine nationalism rejects the presence of indigeneity, U.S. nationalism creates a digestible caricature that legitimizes white, European claims over indigenous people and their land. The Western consumer's preoccupation with knowing the production site and an indigenous narrative that supports their consumption is a form of neocolonialism, or part of what Heldke (2012) calls cultural and economic colonialism because it is "motivated by a deep desire to have contact with, and to somehow own an experience of, an Exotic Other, as a way of making myself more interesting" (2012, 328).

In this paper, I problematize the nationalist undercurrents in marketing and media discourses because I hope that deconstructing imagined national narratives may be one important step towards solutions that can truly address colonization and persisting social inequalities. Although many possibilities for change exist, my analysis underscores the invisibility and 
appropriation of indigenous culture in marketing and, therefore, an important line of policy change both in Argentina and the United States should center on recognizing indigenous rights to land, resources, cultural heritage, and intellectual rights. Some indigenous groups are making progress by shifting the narrative on superfood discourse. As mentioned before, the San and Khoi tribes of South Africa have claimed intellectual rights on South African biodiversity and these legal claims have forced companies like Nestle to give a portion of their profits on their sales of rooibos (Wynberg 2017). While this could be an option for the Guaraní, it can also be a start to greater access to resources, land, and political representation within Argentina.

This thesis mainly focuses on the symbolic representations of food informed by documented socio-economic and historical processes. Additional anthropological studies are needed to continue to analyze the social life of yerba mate. Further studies should center on indigenous experiences with yerba mate production and consumption and relations with other actors like colonos. 


\section{REFERENCES}

Agyeman, Julian and Alison Hope Alkon. 2011. Cultivating Food Justice: Race, Class, and Sustainability. MIT Press Cambridge.

Albes, Edward. 1916. Yerba Mate: The Tea of South America. Pan American Union.

Washington, D.C.: Government Printing Office.

Anderson, Benedict. 1991. Imagined Communities: Reflections on the Origin and Spread of Nationalism. Verso books.

Appadurai, Arjun. 1988. "How to make a National Cuisine: Cookbooks in Contemporary India." Comparative Studies in Society and History 30 (1): 3-24.

Ballvé, Teo. 2007. "Mate on the Market: Fair Trade and the Gaucho’s 'Liquid Vegetable’ Part Two in a Series." NACLA Report on the Americas. 40 (5): 10-13.

Barthes, Roland. (1961) 2012. "Toward a Psychosociology of Contemporary Food Consumption." In Food and Culture, 37-44: Routledge.

Bartolomé, Miguel Alberto. 2004. "Los Pobladores Del “desierto”. Genocidio, Etnocidio Y Etnogénesis En La Argentina." Amérique Latine Histoire Et Mémoire. Les Cahiers ALHIM. (10).

Bennett, T. M. B., N. G. Maynard, P. Cochran, R. Gough, K. Lynn, J. Maldonado, G. Voggesser, S. Wotkyns, and K. Cozzetto, 2014: Ch. 12: Indigenous Peoples, Lands, and Resources. Climate Change Impacts in the United States: The Third National Climate Assessment, J. M. Melillo, Terese (T.C.) Richmond, and G. W. Yohe, Eds., U.S. Global Change Research Program, 297- 317. doi:10.7930/J09G5JR1.

Boisard, Pierre. 2003. Camembert: A National Myth. Vol. 4 Univ of California Press. 
Boyd, Brewster, Nina Henning, Emily Reyna, Daniel Wang, Matthew Welch, and Andrew J. Hoffman. 2017. Hybrid Organizations: New Business Models for Environmental Leadership Routledge.

Bowles, Jennifer. 2013. "Exploring the Dialectic of Labor Rights and Food Sovereignty in Everyday Work Conflicts of Argentina’s Yerba Mate Country.” Conference paper presented at Food Sovereignty: A Critical Dialogue, International Conference, Yale University.

Bruegel, Martin. 2002. "How the French Learned to Eat Canned Food, 1809-1930s." Food Nations: Selling Taste in Consumer Societies, New York, Routledge 113: 130.

Buliubasich, Catalina, Ana Victoria Casimiro Cordoba, and Maria Eugenia Flores. 2016. Mapa Continental “Guarani Retã ”. Salta, Argentina: Consejo Nacional de Investigaciones Científicas y Técnicas (CONICET).

Cavanaugh, Jillian R., Kathleen C. Riley, Alexandra Jaffe, Christine Jourdan, Martha Karrebæk, and Amy Paugh. 2014. "What Words Bring to the Table: The Linguistic Anthropological Toolkit as Applied to the Study of Food." Journal of Linguistic Anthropology24 (1): 84-97.

Ceaser, Mike. 2002. "The Herb that Sustains." Americas 54 (4): 4.

CELS. 2015. Responsabilidad Empresarial En Delitos De Lesa Humanidad.Represión a Trabajadores Durante El Terrorismo De Estado: Editorial Ministerio de Justicia y Derechos Humanos de la Nación.

Cockle, Kristina L., Marty L. Leonard, and A. Alejandro Bodrati. 2005. "Presence and Abundance of Birds in an Atlantic Forest Reserve and Adjacent Plantation of Shade-Grown Yerba Mate, in Paraguay." Biodiversity \& Conservation 14 (13): 3265-3288.

Counihan, Carole and Valeria Siniscalchi. 2013. Food Activism: Agency, Democracy and Economy Bloomsbury Publishing. 
Counihan, Carole and Penny Van Esterik. 2012. Food and Culture: A Reader Routledge.

Crocitti, John J. 2002. "The Internal Economic Organization of the Jesuit Missions among the Guarani." International Social Science Review 77 (1/2): 3-15.

Currid-Halkett, Elizabeth. 2017. The Sum of Small Things: A Theory of the Aspirational Class Princeton University Press.

Deloria, Philip Joseph. 1998. Playing Indian Yale University Press.

Di Leonardo, Micaela. 1998. Exotics at Home: Anthropologies, Others, and American Modernity University of Chicago Press.

Diner, Hasia R. 2003. Hungering for America. Harvard University Press.

Ellis, Markman. 2008. "An Introduction to the Coffee-House: A Discursive Model." Language \& Communication 28 (2): 156-164.

Elyachar, Julia. 2010. "Phatic Labor, Infrastructure, and the Question of Empowerment in Cairo." American Ethnologist 37 (3): 452-464.

Folch, Christine. 2010. "Stimulating Consumption: Yerba Mate Myths, Markets, and Meanings from Conquest to Present." Comparative Studies in Society and History 52 (1): 6-36.

Freedman, Joshua and Dan Jurafsky. 2011. "Authenticity in America: Class Distinctions in Potato Chip Advertising." Gastronomica: The Journal of Critical Food Studies 11 (4): 4654.

Fridell, Gavin. 2007. "Fair-Trade Coffee and Commodity Fetishism: The Limits of MarketDriven Social Justice." Historical Materialism 15 (4): 79-104.

Gabaccia, Donna. 1998. We are what we Eat: Ethnic Food and the Making of Americans Harvard University Press. 
Galafassi, Guido. 2005. "El Movimiento Agrario Misionero En Los Años Setenta. Protesta, Movilización Y Alternativas De Desarrollo Rural." Revista Herramienta 38.

Goebel, Michael. 2011. Argentina's Partisan Past: Nationalism and the Politics of History Oxford University Press.

González, Sara. 2017. Contested Markets, Contested Cities: Gentrification and Urban Justice in Retail Spaces Routledge.

Gortari, Javier. 2007. "La Yerba Mate: Un Rito Guaraní De Proyección Universal." J.Gortari (Comp.), De La Tierra Sin Mal Al Tractorazo.Hacia Una Economía Política De La Yerba Mate, Posadas: Editorial Universitaria De Misiones.

Heldke, Lisa. 2012. "Let's Cook Thai: Recipes for Colonialism." In Food and Culture, 408-422: Routledge.

Hill, Kim and A. Magdalena Hurtado. 2017. Ache Life History: The Ecology and Demography of a Foraging People Routledge.

Hirsch, Silvia. 2004. "Ser guaraní en el noroeste argentino: variantes de la construcción identitaria." Revista de Indias 64, no. 230: 67-80.

Hocsman, Luis Daniel. 2016. "Soberania Alimentaria y Conflictividad Agraria en Argentina. Movimiento Campesino-Indigena, Patrones Rurales y Gobierno a Partir del Paro Agropecuario del 2008." Revista Nera (32): 111-127.

Hooker, Juliet. 2017. Theorizing Race in the Americas: Douglass, Sarmiento, Du Bois, and Vasconcelos Oxford University Press.

Ichijo, Atsuko and Ronald Ranta. 2016. Food, National Identity and Nationalism: From Everyday to Global Politics Springer. 
Jankowiak, William R. and Daniel Bradburd. 2003. Drugs, Labor, and Colonial Expansion University of Arizona Press.

Kopytoff, Igor. 1986. "The Cultural Biography of Things: Commoditization as Process." The Social Life of Things: Commodities in Cultural Perspective 68: 70-73.

Lawson, Janet. 2009. "Cultivating Green Gold: A Political Ecology of Land use Changes for Small Yerba Mate Farmers in Misiones, Argentina." MESc Dissertation.Yale University, New Haven CT: 47-61.

López, Adalberto. 1974. "The Economics of Yerba Mate in Seventeenth-Century South America." Agricultural History 48 (4): 493-509.

Loyer, Jessica. 2016. "The Social Lives of Superfoods." University of Adelaide.

Loyer, Jessica. 2015. "Communicating Superfoods: A Case Study of Maca Packaging." Oxford Symposium on Food and Cookery.

Manning, Paul. 2012. Semiotics of Drink and Drinking A\&C Black.

Manzano, Gillermo Luis and Sandra Duciós. 2019. Incidencia De La Pobreza Y La Indigencia En 31 Aglomerados Urbanos. Buenos Aires: Ministerio de Hacienda.

Marcus, George E. 1995. "Ethnography in/of the World System: The Emergence of Multi-Sited Ethnography." Annual Review of Anthropology 24 (1): 95-117.

Marshall, R. Scott. 2011. "Conceptualizing the International for-Profit Social Entrepreneur." Journal of Business Ethics 98 (2): 183-198.

McGee Deutsch, Sandra. 2016. "Insecure Whiteness: Jews between civilization and barbarism, 1880s-1940s.” In: Rethinking Race in Modern Argentina.

Millman, Heather. 2013. "Daily Dose: Drinking Maté in Asunción, Paraguay." Gastronomica: The Journal of Critical Food Studies 13 (4): 16-21. 
Mintz, Sidney Wilfred. 1986. Sweetness and Power: The Place of Sugar in Modern History Penguin.

Mitchell, Lee Clark. 2014. Witnesses to a Vanishing America: The Nineteenth-Century Response. Vol. 770 Princeton University Press.

Moloney, Anastasia. 2016. "Argentina's Indigenous People Face 'Appalling' Plight: U.N." , 05/25/. https://www.reuters.com/article/us-argentina-indigenous-rights-idUSKCNOYG2K7.

Munasinghe, Viranjini. 2001. Callaloo Or Tossed Salad?: East Indians and the Cultural Politics of Identity in Trinidad Cornell University Press.

Ohnuki-Tierney, Emiko. 1993. Rice as Self: Japanese Identities through Time Princeton University Press.

Pendergrast, Mark. 2010. Uncommon Grounds: The History of Coffee and how it Transformed our World Basic Books.

Pilcher, Jeffrey M. 2017. Planet Taco: A Global History of Mexican Food Oxford University Press.

Pilcher, Jeffrey M. 2008. "Taco Bell, Maseca, and Slow Food: A Postmodern Apocalypse for Mexico's Peasant Cuisine?" Food and Culture: A Reader: 400-410.

Pite, Rebekah E. 2016. "La Cocina Criolla: A History of Food and Race in Twentieth-Century Argentina." In : Rethinking Race in Modern Argentina.

Pite, Rebekah E. 2013. Creating a Common Table in Twentieth-Century Argentina: Doña Petrona, Women, and Food UNC Press Books.

Rau, Víctor. 2009. "La Yerba Mate En Misiones (Argentina): Estructura Y Significados De Una Producción Localizada." Agroalimentaria 15 (28): 49-58. 
Ribeiro M.C., Martensen A.C., Metzger J.P., Tabarelli M., Scarano F., Fortin MJ. 2011. "The Brazilian Atlantic Forest: A Shrinking Biodiversity Hotspot." In Biodiversity Hotspots, edited by Habel J. Zachos F. Berlin, Heidelberg: Springer.

Robertson, James Oliver. 1980. American Myth, American Reality.

Schamis, Hector E. 2002. "Argentina: Crisis and Democratic Consolidation." Journal of Democracy 13 (2): 81-94.

Schiavoni, Gabriela. 1998. Colonos y Ocupantes Parentesco, Reciprocidad y Diferenciación Social En La Frontera Agraria De Misiones. EdUNaM.

Schvorer, Esther. 2011. "Misiones. Estructura Social Agraria, Estado Y Conflictos Sociales. Las Circunstancias De Una Historiografía Regional." XIII Jornadas Inter EscuelasDepartamentos De Historia.San Fernando Del Valle De Catamarca.

Schwarz, Maureen Trudelle. 2005. "Native American Barbie: The Marketing of Euro-American Desires." American Studies 46 (3/4): 295-326.

Scrinis, Gyorgy. 2013. Nutritionism: The Science and Politics of Dietary Advice (New York: Columbia University Press.

Siskind, Janet. 1992. "The Invention of Thanksgiving: A Ritual ofAmerican Nationality." Critique of Anthropology 12 (2): 167-191.

Smith, Franklin. 2014. "Exploring Fair Trade Yerba Mate Networks in Misiones, Argentina."

Sorg, Gustavo. 2008. "Polémica interpretación hace un historiador de su significado y hasta de la forma ortográfica." El Litoral. http://www.ellitoral.com.ar/98914.

Stano, Simona. 2016. "Introduction: Semiotics of Food." Semiotica 2016 (211): 19-26.' 
Wharen, Juan and Luciana Guerreiro. 2014. "Campesinado, Territorios En Disputa Y Nuevas Estrategias De Comercialización De La Producción Campesina En Argentina." Veredas, ano15 (28): 297-342.

Wynberg, R. 2017. "Making Sense of Access and Benefit Sharing in the Rooibos Industry: Towards a Holistic, just and Sustainable Framing." South African Journal of Botany 110: $39-51$.

Zarranz, Luis. 2018. "Argentina - Tierra De Tareferos: Esclavitud Siglo XXI En Los Yerbales De Misiones." Brecha, January 19,. https://correspondenciadeprensa.com/2018/01/22/argentina-tierra-de-tareferos-esclavitudsiglo-xxi-en-los-yerbales-de-misiones/.

Zwier, Sandra. 2009. "Research Report: Medicalisation of Food Advertising. Nutrition and Health Claims in Magazine Food Advertisements 1990-2008." Appetite 53: 109-113. doi:10.1016/j.appet.2009.05.017. http://libproxy.lib.ilstu.edu/login?url=https://search.ebscohost.com/login.aspx?direct=true\& $\mathrm{db}=$ edselp\&AN $=\mathrm{S} 0195666309005340 \&$ site $=$ eds-live \&scope $=$ site. 